\title{
OPEN ACCESS TO BROADBAND NETWORKS: A CASE STUdy OF THE AOL/TIME WARNER MERGER
}

\author{
By Daniel L Rubinfeld and Hal J. Singert
}

\begin{abstract}
This Article provides a framework for the analysis of the potential effects of the recent AOL/Time Warner merger on the markets for broadband Internet access and broadband Internet content. We consider two anticompetitive strategies that a vertically integrated firm such as AOL Time Warner, offering both broadband transport and portal services, could in theory profitably pursue. First, an integrated provider could engage in conduit discrimination -insulating its own conduit from competition by limiting its distribution of affiliated content and services over rival platforms. Second, an integrated provider could engage in content discrimination-insulating its own affiliated content from competition by blocking or degrading the quality of outside content. After examining the competitive conditions in the broadband portal and transport markets, we evaluate the post-merger incentives of AOL Time Warner to engage in either or both forms of discrimination.
\end{abstract}

\section{TABle of Contents}

I. INTRODUCTION

II. RELEVANT ANTITRUST MARKETS AFFECTED BY THE MERGER …........................6.635

III. AOL'S PRE-MERGER BROADBAND INTERNET STRATEGY ...................................638

IV. AOL TIME WARNER'S POST-MERGER ABILITY TO ENGAGE IN CONDUIT OR CONTENT DISCRIMINATION

A. Post-Merger Ability to Engage in Conduit Discrimination

1. Availability of Broadband Portal Substitutes for Rival Broadband Conduits.

2. Availability of Substitute Broadband Transport Services for Broadband Consumers.

B. Post-Merger Ability to Engage in Content Discrimination

1. Availability of Alternative Broadband Customers

2. Minimum Viable Scale and the Marginal Cost of Broadband Content ..654

(C) 2001 Daniel L Rubinfeld and Hal J. Singer.

$\dagger$ Rubinfeld is Robert L. Bridges Professor of Law and Professor of Economics at the University of California, Berkeley.

$\ddagger$ Singer is Senior Vice President of Criterion Economics. The authors wish to thank Glenn Woroch for his helpful comments. 
V. AOL TIME WARnER'S InCEnTIVEs to Engage IN CONDUIT OR CONTENT DISCRIMINATION.

A. Theoretical Models of Foreclosure …......................................................65

B. Post-Merger Incentives to Engage in Conduit Discrimination .....................657

I. Necessary Conditions for Conduit Discrimination ..............................657

2. Example of Conduit Discrimination in the Cable Television Industry ...663

C. Post-Merger Incentives for Content Discrimination .....................................664

1. Necessary Conditions for Content Discrimination ..............................664

2. Example of Content Discrimination in the Cable Television Industry ...671

VI. IMPLICATIONS FOR CONDITIONS ON THE MERGER OF AOL AND TIME WARNER ....672

\section{INTRODUCTION}

The increasing number of mergers in high-technology industries has raised both horizontal and vertical antitrust issues. While horizontal issues have been the subject of continual scrutiny by the antitrust authorities, the interest in and analysis of vertical issues has come to the forefront during the past eight years. This Article evaluates one concern that can arise in vertical mergers - the possibility that the merged firm will utilize its market power in one market to foreclose competition in related vertical markets. Two recent mergers involving broadband access typify the mix of horizontal and vertical issues that arise in many high-technology mergers. The merger of AT\&T and MediaOne represented a horizontal combination of two of the largest broadband Internet Service Providers ("ISP"). Recognizing the potentially anticompetitive impact of such a combination, the Department of Justice ("DOJ") required that AT\&T divest MediaOne's interest in one of these ISPs, Road Runner, as a condition of merger approval. ${ }^{1}$ In contrast, the merger of AOL and Time Warner involved a vertical combination of the largest Internet content provider and aggregator with one of the largest cable system operators. Although traditional antitrust analysis applies in both cases, the Internet forces us to reconsider antitrust theory, recognizing that there are a variety of new ways in which firms may engage in anticompetitive behavior.

Vertical foreclosure concerns are not specific to the Internet or to broadband access. These concerns are relatively new, however, having begun to appear regularly in antitrust investigations in the mid-1990s. For example, in its 1994 challenge to the acquisition of Liberty Media Corporation by Tele-Communications Inc. ("TCI"), the DOJ required the two

1. See Plaintiff's Competitive Impact Statement at 13-15, United States v. AT\&T Corp., 2000 U.S. Dist. LEXIS 11459 (D.D.C. May 25, 2000) (No. 1: 00CV00176) (competitive impact statement) (explaining that the proposed merger "would violate Section 7 of the Clayton Act, 15 U.S.C. $\$ 18$, by lessening competition in the nationwide market for the aggregation, promotion, and distribution of residential broadband content." $I d$. at 1.). 
parties to supply their video programming on a nondiscriminatory basis to other multichannel television providers. ${ }^{2}$ Then, in November 1995, the U.S. Federal Trade Commission ("FTC") approved a consent decree with Silicon Graphics, Inc. ("SGI"), which allowed SGI to acquire two leading software companies if it agreed to make two major entertainment graphics software programs compatible with the hardware workstations of a competitor. ${ }^{3}$ More recently, the FTC approved the merger of Time Warner and Turner Broadcasting System, Inc. ("TBS"), subject to an agreement that prohibited Time Warner from discriminating in price or refusing to supply TBS programming to rival multichannel television providers. ${ }^{4}$

Although each case involving vertical foreclosure issues is different, the overarching economic and legal issues are similar. As a result, we believe that an in-depth analysis of one merger can yield insights that are general to most vertical mergers that raise foreclosure concerns. In this Article, we examine the issues raised by the recent merger of AOL and Time Warner.

The means by which the merger of AOL and Time Warner represented a vertical combination in the market for residential broadband Internet service are straightforward. ${ }^{5}$ According to at least one industry observer, AOL offered Time Warner specialized skills in readying content for the Internet:

That Time Warner, with its brands, content and distribution channels, has embraced this deal so enthusiastically is an extraordinary admission of the difficulty that many traditional companies face when trying to adapt their businesses to the

2. See United States v. Tele-Communications, No. 94-0948, 1994 U.S. Dist. LEXIS 20983 (D.D.C. Aug. 19, 1994).

3. In re Silicon Graphics Inc., No. 951-0064, 1995 F.T.C. LEXIS 159 (July 5, 1995) (proposed Consent Agreement); FTC, FYI: FTC Approves Consent Agreement with Silicon Graphics, Inc., Nov. 16, 1995, at http://www.ftc.gov/opa/1995/9511/ sil2g.html (announcing that the Consent Agreement issued in final form on November 14, 1995).

4. In re Time Warner, Inc., 123 F.T.C. 171 (1997). The FTC had been particularly concerned that Time Warner's cable rivals might be foreclosed from obtaining programming. See id. at 207 (statement of Chairman Robert Pitofsky and Comm'rs Janet D. Steiger and Christine A. Varney).

5. For evidence on the existence of a separate antitrust market for residential broadband Internet service, as compared to narrowband Internet service, see Jerry A. Hausman et al., Residential Demand for Broadband Telecommunications and Consumer Access to Unaffiliated Internet Content Providers, 18 YALE J. ON REG. 1, 8-28 (2001). 
Internet. Its own in-house efforts to move the company in that direction have pretty much failed. ${ }^{6}$

AOL's input was not solely its proprietary content. Rather, AOL's contribution was its unique aggregation and presentation of content that allowed for easy consumption by end users. For example, a rare Time Warner video placed on the Internet might never be noticed if not for AOL's packaging and distribution. To complement AOL's upstream input, Time Warner offered the conduit over which such content would reach residential broadband customers at high speeds. While the framework is quite broad, our analysis in this Article focuses on the incentives created by the vertical nature of the AOL/Time Warner relationship.

Our analysis suggests that, absent suitable remedies, the merger will create strong incentives for AOL Time Warner to discriminate against unaffiliated conduits and content providers. To combat these significant risks of discrimination, we conclude that it was appropriate for the FTC to seek conditions on the AOL Time Warner merger that would require the combined company to open its cable modem platform to unaffiliated portals on nondiscriminatory terms. Similarly, it was appropriate for the Federal Communication Commission ("FCC") to undertake an inquiry in September 2000 into the legal and policy approaches to be accorded to high-speed Internet service provided over various platforms.?

Part II defines the relevant antitrust markets affected by the merger. Part III explains AOL's pre-merger strategy with respect to placement of its portal service over alternative conduits. Part IV examines the competitive conditions in the broadband portal and transport markets, with a particular emphasis on determining whether a combined AOL Time Warner will have the ability to raise content prices or cut off access to its content over competing conduits. Part V examines the post-merger incentives of AOL Time Warner to engage in conduit, and then in content discrimination. This includes discussions of the relevant economic theory, historical examples of discrimination in the cable television industry, and applications of the theory to the merger.

6. The Big Leap, THE ECONOMIST, Jan. 15, 2000, at 17.

7. See In re Inquiry Concerning High-Speed Access to the Internet Over Cable and Other Facilities, 155 F.C.C.R. 19287, II 14 (2000). 


\section{RELEVANT ANTITRUST MARKETS AFFECTED BY THE MERGER}

Consumers entering into the broadband Internet service market must secure access to many inputs, including: (1) broadband content (e.g., streaming video and audio, movies, video conferencing, and interactive games); (2) the aggregation of broadband content and complementary services (e.g., chat rooms and instant messaging) by a broadband portal; (3) connectivity to the Internet supplied by a broadband ISP; and (4) highspeed transport from the home to the ISP supplied by a cable provider, telephone company, or other broadband conduit provider. Distinctions between these layers of inputs may not, however, be readily apparent to consumers. Some broadband portals (such as Yahoo!) offer broadband content only, while other broadband portals (such as AOL) offer a bundle that includes both broadband content and connectivity to the Internet. Further, cable operators historically have tied together the purchase of all four inputs, requiring customers seeking a high-speed cable connection to the Internet to purchase portal service and broadband content from the cable operator's affiliated ISP.

To simplify the exposition that follows, we will aggregate these four inputs into two distinct antitrust markets. First, we define the downstream market (input 4 above) as broadband transport service-a market served by cable providers, telephone companies, and any other firm that provides consumers transport from the home to an ISP at speeds exceeding 200 $\mathrm{Kbps}^{8}$ Second, we define the upstream market (inputs 1, 2, and 3 above) as broadband portal service-a market served by all firms that create, package, and distribute broadband content and ancillary services, regardless of whether they are ISPs (like AOL) or pure portals (like Yahoo!). We believe that this set of market definitions accurately reflects the functional differences between the services offered by conduit providers and content aggregators. Further, it comports with the distinctions between separate broadband services drawn by the Ninth Circuit Court of Appeals in its re-

8. The FCC defines broadband as "having the capability of supporting, in both the provider-to-consumer (downstream) and the consumer-to-provider (upstream) directions, a speed (in technical terms, 'bandwidth') in excess of 200 kilobits per second (kbps) in the last mile." (This definition explicitly excludes access by dial-up modems.) See In re Inquiry Concerning the Deployment of Advanced Telecommunications Capability to All Ams., 144 F.C.C.R. 2398 , II 20 (1999). 
cent $A T \& T$ v. City of Portland decision, ${ }^{9}$ and by the Justice Department in its complaint against AT\&T and MediaOne. ${ }^{10}$

These market definitions suggest two anticompetitive strategies that a vertically integrated firm, offering both broadband transport and portal services, could in theory profitably pursue. First, an integrated provider could engage in conduit discrimination-insulating its own conduit from competition by limiting its distribution of affiliated content and services over rival platforms. Conduit discrimination could involve a range of anticompetitive strategies, from refusing to distribute an affiliated portal over competing conduits, to making marquee content available only to customers using an affiliated conduit. (AOL Time Warner could, for example, curtail its marketing of AOL's service over Digital Subscriber Lines ("DSL") while actively promoting the service over cable.) Second, an integrated provider could engage in content discrimination-insulating its own affiliated content from competition by blocking or degrading the quality of outside content. Content discrimination could involve a range of strategies, from blocking outside content entirely, to affording affiliated content preferential caching treatment. ${ }^{11}$ (A combined AOL Time Warner could, for example, provide preferential caching service to its affiliated CNN-Sports Illustrated site, while providing inferior caching support to the Walt Disney Corporation's ESPN site.)

Because discrimination against rivals is not foreign to either AOL or Time Warner, it is necessary to analyze rigorously whether a merged AOL Time Warner will have the incentive and ability to engage in content and conduit discrimination. Time Warner has already demonstrated its ability to block unaffiliated content from its cable systems in its recent dispute with $\mathrm{ABC} .{ }^{12}$ With respect to granting access to competing ISPs over the same conduit, Time Warner has demonstrated an unwillingness to extend reasonable interconnection terms to nonaffiliated ISPs. For example, under

9. 216 F.3d 871, 878 (9th Cir. 2000) (the court concluded that cable modem service consists of "two elements," a "pipeline" and "the Internet service transmitted through that pipeline").

10. Amended Complaint at TाT15, 25, U.S. v. AT\&T Corp., 2000 U.S. Dist. LEXIS 14459 (D.D.C. May 26, 2000) (No. 1:00CV001176) (DOJ distinguished between markets for "transmission facilities that are capable of carrying data at a high rate" and portals engaged in the "aggregation, promotion, and distribution of broadband content and services").

11. Communications Daily Notebook, COMM. DAILY, May 11, 2000 ("Caching technology allows popular websites to be stored closer to end user, possibly at cable headend, in order to avoid Internet backbone delays.").

12. Jim Rutenberg, Time Warner and Disney Reach Cable Deal for $A B C$, N.Y. Times, May 26, 2000, at C6. 
a confidential term sheet provided to forty nonaffiliated ISPs in Texas, Time Warner would receive 75 percent of the Internet service providers' revenue from all subscriber fees, 25 percent of the Internet service providers' revenue from sources such as advertising and other e-commerce fees, and a $\$ 50,000$ upfront deposit. ${ }^{13}$ Moreover, Time Warner insisted on provisions that would effectively give it the ability to co-brand the websites of rival ISPs and control the content on the most important page of an ISP's sites. $^{14}$

AOL also has a history of discrimination. For example, by making its Instant Messenger ("IM") software incompatible with rival private-text chat software, ${ }^{15}$ AOL has foreclosed rival private-text chat software providers such as iCAST from gaining access to AOL's IM community. ${ }^{16}$ In October 2000, the Walt Disney Corporation revealed that AOL had imposed contractual conditions that aimed to deter users from leaving AOL's network to reach competitors on the web. ${ }^{17}$ Under one contractual provision, if 25 percent or more of Disney's traffic left AOL's offerings, AOL could cancel the contract with Disney. ${ }^{18}$ Disney agreed to AOL's terms because "it felt that it needed access to AOL's vast network of consumers." $" 19$

AOL's efforts in this regard are examples of both content and conduit discrimination, as AOL has precluded its IM customers from speaking to outsiders (blocking outside content) and has barred competing IM platforms from accessing AOL's customers (limiting distribution over competing platforms). That AOL has done so, despite the fact that its own customers would prefer to communicate with as wide a range of people as possible, confirms that AOL is willing to degrade the quality of its cus-

13. Alec Klein, Time Warner Terms for Cable Criticized, WASH. POST, Oct. 7, 2000, at E1.

14. Id.

15. Comments of iCast Corp. at 4, In re Applications for Consent to the Transfer of Control of Licenses and Section 214 Authorizations by Time Warner Inc. and Am. Online, Inc., Transferors, to AOL Time Warner, Inc., Transferee, 2001 F.C.C. LEXIS 432 (Jan. 22, 2001) (No. 00-30), http://www.fcc.gov/transaction/aol-tw/ icast_comment042500.pdf (explaining that "the only barrier to the explosion of new innovations and uses in the [instant messaging] market is AOL's insistence that a large part of the market be off limits to other segments of the same market").

16. In June 2000, AOL sent a proposal to the Internet Engineering Task Force that outlined how it could make its instant messaging system work with competing systems, but did not commit to any timetable. See Julia Angwin, AOL Submits Plan to Allow Access To Message System, WALL ST. J. EUR., June 16, 2000 , at UK4.

17. Alec Klein, AOL Restrictions Alleged, WASH. POST, Oct. 10, 2000, at E1.

18. Id.

19. Id. 
tomers' experience when doing so would add to its competitive advantage. ${ }^{20}$ AOL's history of discrimination suggests that antitrust enforcers should vigorously scrutinize any possibility of future discrimination.

\section{AOL'S PRE-MERGER BROADBAND INTERNET STRATEGY}

Prior to its proposed merger with Time Warner, AOL's broadband Internet strategy flowed from its larger objective of maximizing the profits of its Internet service and content businesses. Because AOL's profits did not depend on the conduit by which customers viewed its content, AOL potentially served as the largest "conduit-neutral" broadband portal. Indeed, AOL stated its broadband Internet intentions five months before the announcement of the Time Warner merger in a filing with the Securities and Exchange Commission:

The Company has established its 'AOL Anywhere' strategy of making the AOL service and features available through multiple connections and multiple devices.... The Company's next generation software for the AOL service, AOL 5.0, which will be introduced in the fall of 1999, will include the new feature AOL Plus, which will enable members to connect to the AOL service through high-speed broadband technologies, including DSL, cable, satellite and wireless, and will provide additional online content to members connecting through such broadband technolo-

20. Further, by demanding that its narrowband content providers (such as AutoNation, Monster.com, 1-800-FLOWERS.COM, and CBS News) refrain from advertising rival ISPs on their Web sites in return for exclusivity, AOL has foreclosed rival ISPs from gaining access (through at least one channel) to AOL's customers. See 1-800FLOWERS.COM, INC., 1999 SEC FORM 10-K, exhibit 10.22, term 2.8.2(a)(i). 1-800FLOWERS stipulated that it cannot

promote, advertise or market the Products, services or Content of (a) any Interactive Service other than AOL or (b) except as not prohibited under Section 2.8.2 (a) (iv), any entity reasonably construed to be in competition with any third party with which AOL has an exclusive or premier (i.e., exclusivity granted by AOL to more than one third party in a particular category) relationship....

Id.; Jim Hu \& Mike Yamamoto, AOL's Squeeze Play: Partners Face High Price of Doing Business with Online Giant, CNET NEWS, Mar. 1, 2000, at http://news.cnet.com/ news/0-1005-201-1556048-0.html (describing how AOL insisted that OnQ, a gay and lesbian online community, refuse all advertising from Internet service providers deemed to be competitors). 
gies. The expanded content will include video, games, music and online catalogue shopping features. ${ }^{21}$

Although AOL might have been concerned about managing the dual revenue streams from narrowband and broadband customers, the choice of conduit within the broadband industry on AOL's profitability was irrelevant. Thus, lacking any significant interest in any particular broadband conduit, pre-merger, AOL maintained a strong incentive to make its service available over all broadband platforms.

The broadband competitive landscape had become hostile to AOL, however, as cable providers instituted a tying strategy; broadband customers needed to purchase their own broadband portal service in conjunction with broadband transport. ${ }^{22}$ There is a two-fold strategic motivation for tying portal service to broadband transport. First, by denying outside providers access to the number of customers needed to maintain minimum efficient scale, tying discourages competitive entry into the broadband portal market and allows cable providers to extend their market power upstream. Second, by capitalizing on cable's early lead in broadband deployment, tying allows cable providers to align the full strength of their customer base behind a small number of portals. The network effects generated by this strategy allow cable providers to attract marquee content to their portals and, at the same time, raise barriers to entry for other firms seeking to offer competing portal and transport services. ${ }^{23}$ Over the long term, the cable providers' tying strategy will thus undermine competitive investment in both the broadband transport and portal markets, insulate cable providers from conduit and content competition, and ensure that the delivery of Internet-based video by competing conduits does not erode cable providers' monopoly power in the market for traditional video programming. ${ }^{24}$

21. AMERICA ONLINE INC., 1999 SEC FORM 10-K, at 8.

22. The issue was first raised at the national level during the merger proceedings between AT\&T and Tele-Communications, Inc. See, e.g., Comments of Am. Online, Inc. at app. A, II 7, In re Joint Applications of AT\&T Corp. and Tele-Communications, Inc., No. 98-178 (1998) (declaration of Prof. Jerry A. Hausman).

23. For a discussion of network effects, see, for example, Nicholas Economides, The Economics of Networks, 14 INT'L. J. INDUS. ORG. 673 (1996).

24. See, e.g., U.S. General ACCOUNTING OfFice, Telecommunications: The EFFECT OF COMPETITION From SATELlite Providers on CABLE RATES 5 (2000) ("Cable television is currently the dominant means of television program delivery to U.S. households."). 
The impact of this tying strategy on competing portals has been significant. Within two years of initiating their tying arrangement, verticallyintegrated cable firms such as AT\&T succeeded in convincing a substantial percentage of customers to sever their ties with competing ISPs. Thus, 66 percent of @Home users had previously been AOL users, but had since cancelled their AOL accounts; ${ }^{25}$ because consumers received broadband Internet service with the purchase of broadband transport, maintaining their subscriptions to AOL amounted to paying twice for the same services.

AOL's initial response to this exclusionary threat was to organize a legal and political campaign to obtain "open access" to the cable conduit. ${ }^{26}$ AOL also negotiated a series of agreements with the largest incumbent local carriers-Bell Atlantic, SBC, GTE-to provide services over DSL. ${ }^{27}$ Nevertheless, when its open access campaign failed at the FCC, and when the technical difficulties associated with a national rollout of DSL became apparent, AOL elected to acquire a significant interest in the cable conduit itself, agreeing to purchase Time Warner in January 2000 for $\$ 131.5$ billion. ${ }^{28}$

With a successful acquisition, AOL would no longer be as dependent on the cable providers' willingness to offer open access to cable customers. Indeed, merging with Time Warner would only enhance AOL's bargaining position with AT\&T-now the nation's largest cable providerbecause AT\&T already has significant overlapping ownership interests in Time Warner. ${ }^{29}$ Moreover, as of the summer of 2000, AT\&T and Time

25. David Simons, AOL Jolted by MS/AT\&T Deal, RED HERRING, May 6, 1999, at http://www.redherring.com/index.asp?layout=story_generic\&doc_id=RH1240011124.

26. AOL organized a coalition of firms under the name openNET Coalition and began lobbying the FCC during the merger proceedings of AT\&T and TeleCommunications. See, e.g., Leslie Scism \& Thomas E. Weber, Some Analysts Support AOL's Efforts to Gain Access to Internet Afforded to Cable Operations, WALL ST. J., Nov. 12, 1998, at C2 (describing how AOL was "lobbying the FCC hard to force cable companies to 'unbundle' broadband Internet access").

27. See Bell Atlantic to Offer Special ADSL Service for AOL, COMM. DAlly, Jan. 14, 1999, at 1; Press Release, Am. Online, Inc., America Online and SBC Communications to Offer High Speed Upgrade to AOL Members (Mar. 11, 1999), at http://media.aoltimewarner.com/media/cb_press.cfm; Press Release, Am. Online, Inc., America Online and GTE to Bring Broadband ADSL Service to AOL Members (July 27, 1999), at http://media.aoltimewarner.com/media/cb_press.cfm.

28. Nikhil Deogun \& Nick Wingfield, Stock Drops Spur Questions on AOL DealExecutives Argue for Pact, But More Price Declines Could Affect Prospects, WALL ST. J., Jan. 13, 2000, at A3.

29. Because AT\&T acquired a 25 percent stake in Time Warner Entertainment through its acquisition of MediaOne and already held a 9 percent interest in Time War- 
Warner were in the advanced stages of negotiations over a joint venture that would grant AT\&T the exclusive right to provide telephone service over Time Warner's cable lines. ${ }^{30}$ The likelihood of a contractual arrangement between AT\&T and AOL-whereby AOL Time Warner would secure rights to distribute its portal service over AT\&T's cable systems, and AT\&T would secure exclusive rights to provide telephone service over AOL Time Warner's cable systems-thus appears to be very real. ${ }^{31}$

Simply put, the acquisition of Time Warner presents AOL with a second, complementary profit stream to its existing portal business-the sale of broadband transport-thereby altering its overall broadband incentives. Further, it significantly improves the chances that AOL will negotiate a contract with AT\&T for acess to AT\&T's cable lines. The following sections examine how the merger-and a possible deal between a combined AOL Time Warner and AT\&T-will change AOL's incentives to foreclose its upstream and downstream rivals. These sections further ask whether the competitive conditions in the broadband portal and transport markets will accommodate such a strategy.

\section{AOL TIME WARNER'S POST-MERGER ABILITY TO ENGAGE IN CONDUIT OR CONTENT DISCRIMINATION}

Professors Michael Riordan and Steven Salop propose a useful framework for evaluating the competitive effects of vertical mergers. ${ }^{32}$ Most importantly, they highlight those factors that would limit the merging firm's ability to engage in conduit or content discrimination. ${ }^{33}$ In the following sections, we adopt this approach to analyze whether AOL Time Warner would have the ability to discriminate against rival conduits or content providers.

ner, Inc. through its Liberty Media subsidiary, and because AOL acquired cable conduits though its acquisition of Time Warner, the interests of the two former-broadband rivals have come into alignment. See, e.g., Brigitte Greenberg, Media Mergers Prompt Challenges, CHATTANOOGA TMES, June 27, 2000, at C2.

30. See, e.g., Sara Hammel, Cable Guy and the Operator: AT\&T Goes Local with Time Warner, U.S. NEWS \& WORLD REP., Feb. 10, 1999, at 47.

31. Indeed, AT\&T recently concluded an agreement to provide telephone service over the cable systems of Insight Communications. Insight Communications and AT\&T Finalize Agreement to Offer Local Telephone Service, PRNEWSWIRE, July 24, 2000.

32. See Michael H. Riordan \& Steven C. Salop, Evaluating Vertical Mergers: A Post-Chicago Approach, 63 ANTTRUST L. J. 513 (1995).

33. Professors Riordan and Salop use the terms "input-level" and "customer-level" discrimination. $I d$. at 527 . To eliminate any confusion, we have replaced their terms with "conduit" and "content" discrimination. 


\section{A. Post-Merger Ability to Engage in Conduit Discrimination}

In determining whether AOL Time Warner would have the ability to engage in conduit discrimination, we must consider two competitive responses by foreclosure targets. First, we must determine whether downstream conduit rivals could "substitute" equally cost-effective alternative inputs for the portal service or content withheld by AOL Time Warner. This inquiry requires us to ascertain whether a foreclosed conduit provider could find another portal equally attractive to consumers if AOL decided not to market its service over that platform, or could itself enter the portal market and create a new service equally attractive to the one withheld by AOL. Second, we must determine whether end users could switch to alternative broadband conduits unaffected by AOL Time Warner's foreclosure strategy. Hence, to understand the competitive position of AOL with respect to other broadband portals, we must first analyze the degree of competition in the broadband portal market. The second question necessitates a similar analysis of the broadband transport market.

\section{Availability of Broadband Portal Substitutes for Rival Broadband Conduits}

Professors Riordan and Salop suggest that several factors should be analyzed to determine the likely supply response of unaffiliated input providers to an increase in the price, or decrease in the supply, of the vertically-integrated firm's upstream product. ${ }^{34}$ The first step is to identify the hypothetical market of "equally cost-effective" nonforeclosed input suppliers. $^{35}$

A broadband portal aggregates media-rich content that can be viewed by broadband users. Such a portal can either produce its own content or purchase content from independent producers. To achieve success, however, a broadband portal must offer a wide array of content that takes advantage of a high-speed Internet connection; doing so is the only way to attract customers who typically demonstrate a significant degree of loyalty to one portal. Given this linkage between access to broadband content and the success of a broadband portal, any impediment to entry in the content market will also inhibit entry into the portal market.

As indicated above, it is appropriate to narrow our focus of nonforeclosed input suppliers to those nonforeclosed suppliers that are "equally cost-effective." Delivery of broadband portal services is subject to significant economies of scale-for example, the cost of production and distribu-

34. Id. at 530-38.

35. Id. at 530 . 
tion of the last streaming video is significantly less than production and distribution of the first-that a broadband portal must enjoy to achieve cost parity. As Tom Jermoluk, the former CEO of @Home, explained in April 1998, @Home had "the economies of scale resulting from both dealing with media companies on a national level as well as the technology vendors that are necessary." ${ }^{36}$ Recently, George Bell, the new CEO of Excite@Home, reiterated the importance of economies of scale in providing broadband portal service:

Content seeks ubiquity. Content seeks the greatest number of eyeballs possible, and clearly through the avenue of Excite@Home onto the systems of AT\&T, Cox, Comcast, and our other partners, and with these extensions, I've got to believe we are the most attractive broadband aggregator and therefore broadband partner to content companies. We will be able to attract richer forms of content and more content providers because we will continue to be ... the leaders in broadband. We will have the most subscribers and the greatest size footprint in which to market those subscribers. ${ }^{37}$

According to one industry analyst, unaffiliated websites "that don't have resources to market themselves like big media companies will fade into the digital twilight." 38

To the extent that the costs of producing marquee streaming video for the Internet mirror those of producing content for cable television, any economies of scale would likely translate from one medium to another. ${ }^{39}$ For example, most of the production costs of broadband Internet content, like cable television content, are upfront costs, while the marginal costs (for example, the costs of distribution) are negligible. ${ }^{40}$ These up-front costs are very high, particularly for a portal seeking to develop content

36. Tom Jermoluk, The @Home Network, INTERACTIVE HOME, Apr. 1, 1998.

37. George Bell, CEO Excite@Home, AT\&T Conference Call, Mar. 29, 2000.

38. Hu \& Yamamoto, supra note 20 (quoting Jeff Chester, Executive Director, Center for Media Education).

39. See, e.g., Bruce M. OWen, The INTERNEt Challenge to Television 51 (1999) (explaining the similarities in cost structures between "pre-electronic and electronic media").

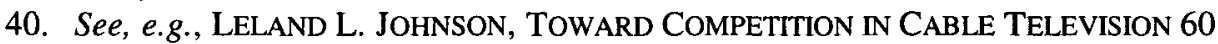
(1994) (explaining how "programming investments and profits automatically rise by the same percentage that a video program's potential audience rises"). For the effects of scale on media product distribution, see James N. Rosse, Daily Newspapers, Monopolistic Competition, and Economies of Scale, 57 AM. ECON. REv. 522 (1967); BRUCE M. OWEN, ECONOMICS AND FREEDOM OF EXPRESSION (1975); BRUCE M. OWEN \& STEVEN S. WILDMAN, VIDEO ECONOMICS (1992). 
that can compete with CNN and other AOL Time Warner marquee content. Indeed, when evaluating Time Warner's earlier merger with Turner Broadcasting in 1997, FTC Chairman Robert Pitofsky, along with FTC Commissioners Janet Steiger and Christine Varney, recognized that there exist "formidable entry barriers into programming" and that entry into the market for "marquee" content "has proven slow and costly." 41 Moreover, the FTC's majority recognized that a very large audience was required to support the development of new programming, finding that, "[b]ecause of the economies of scale involved, the successful launch of any significant new channel usually requires distribution on MPVDs [multi-channel video programming distributors] that cover 40 to 60 percent of all subscribers." 42 Further, the majority concluded that programmers could not support new offerings by relying on technologies or partners other than market leaders, because replicating "the coverage of these systems by lacing together agreements with the large number of much smaller MVPDs is costly and time consuming." ${ }^{, 3}$ Based on these conclusions, the majority found that the risk of vertical foreclosure in the video programming market was "both real and substantial."

Given the shared set of inputs used in the production of video streaming content for both mediums, the efficient scale in the production and aggregation of broadband content is likely to be equally large, and barriers to entry in the broadband portal market equally formidable. Indeed, over and above the costs of producing new content, developers of broadband portals require a large number of servers, additional bandwidth, and sophisticated compression software to encode video and audio files for speedier transmission over the Internet. Further, entrants in this market face the uncertainty associated with new and untested business models, the risks of which are apparent when one looks at Time Warner's own failed effort to launch a "marquee" broadband site. ${ }^{45}$

Because the cost of producing and aggregating broadband content reflects significant economies of scale, we restrict the relevant domain to those broadband portals accessed by a substantial share of broadband cus-

41. In re Time Warner Inc., 123 F.T.C. 171, 207 (1997) (statement of Chairman Robert Pitofsky and Comm'rs Janet D. Steiger and Christine A. Varney).

42. Id.

43. Id.

44. Id.

45. Alexei Oreskovic, Broadband or Bust, THE STANDARD, June 12, 2000, at http://www.thestandard.com/article/display/0,1151,15755,00.html (noting the exit of Digital Entertainment Network and Pixelon). 
tomers. Table 1 shows a list of broadband Internet portals that are accessed by more than 15 percent of total broadband users. ${ }^{46}$

Table 1: Internet Portals Visited by Broadband Users, 1999

\begin{tabular}{l|l|l|l|l}
\hline $\begin{array}{l}\text { Internet } \\
\text { Site }\end{array}$ & $\begin{array}{l}\text { Percent }_{\text {Reach }^{\mathrm{a}}} \\
\text { Yahoo! }\end{array}$ & Portal & $\begin{array}{l}\text { Streaming } \\
\text { Video }\end{array}$ & $\begin{array}{l}\text { Vertically } \\
\text { Integrated }^{-}\end{array}$ \\
\hline Altavista & 46 & Yes & Yes & No \\
Excite@Home & 40 & Yes & Yes & No \\
Lycos & 38 & Yes & Yes & Yes \\
MSN & 31 & Yes & Yes & Yes \\
Netscape & 29 & Yes & Yes & Yes \\
Snap & 23 & Yes & Yes & No \\
Go/Infoseek & 22 & Yes & Yes & No \\
AOL & 16 & Yes & Yes \\
\hline
\end{tabular}

Source: Daniel Roth, Surprise! Yahoo Goes Broadband, Yahoo Has No Megamerger Like AOL/Time Warner or Excite@Home, FORTUNE, May 29, 2000, at 182 (citing Cyber Dialogue study).

${ }^{\text {a }}$ Percentage of individuals that accessed the content of a specific site from among the total number of individuals using the web or online services during any month in 1999. Because AOL is largely denied access to cable broadband customers, its score is comprised primarily of DSL customers.

As Table 1 demonstrates, many of the top broadband portals are vertically integrated into conduits. Those vertical relationships will ensure that a handful of broadband content providers will achieve sufficient scale to remain viable. In addition to the combined AOL Time Warner, Ex-

46. We define a broadband site as any website that (1) offers multimedia data at transmission rates faster than $56 \mathrm{Kbps}$, and (2) takes advantage of the always-on connections available to consumers with cable and DSL. We note that the FCC has designated $200 \mathrm{Kbps}$ (upstream and downstream) as the point at which broadband services begin. See In re Inquiry Concerning the Deployment of Advanced Telecommunications Capability to All Ams., 144 F.C.C.R. 2398 (1999). 
cite@Home (the third most popular site) is owned by AT\&T, Microsoft (the fifth most popular site) shares in the profits of AT\&T's cable lines, and Netscape (the sixth most popular site) is owned by AOL. It is no accident that the list is dominated by vertically integrated content providers-a cable conduit has a strong incentive to make sure that its customers are steered to its content. In June 2000, Excite@ Home attempted to solidify its position in the broadband portal market by launching Excite ClickVideo, a broadband distributor of videos made particularly for the Internet. ${ }^{47}$ Moreover, Excite@ Home has already entered into distribution agreements with iFilm, AtomFilms, Bloomberg News, Comedy Central, FoxNews.com, Mondo Media, Quokka Sports, and Showtime Networks. ${ }^{48}$

A small number of well-financed nonintegrated broadband content providers, such as Yahoo!, have also made large investments to compete for broadband customers. In July 1999, Yahoo! purchased Broadcast.com, a pioneer in the aggregation of streaming audio and video clips, for \$5.7 billion. ${ }^{49}$ In March 2000, Yahoo! launched FinanceVision, a site that offers live business news to customers at work. ${ }^{50}$ Yahoo!'s broadband sites will be funded by thirty second "multi-media spots," but whether these investments will pay off is an open question. ${ }^{51}$ The number of customers who view the advertisements-and hence generate Yahoo's most important revenue stream-critically depends on each conduit provider's willingness to refrain from content discrimination. Recent reports indicate that nonintegrated broadband portals such as Yahoo! and Lycos are reducing their broadband production efforts due to a concern about the extent of broadband traffic, while Excite@Home, which is able to aggregate large numbers of customers as a result of its closed system, can confidently "shift the majority of its resources and personnel toward developing content and applications for broadband users."

The above analysis demonstrates that the broadband portal market is moderately concentrated and is likely to experience further consolidation.

47. Gwendolyn Mariano, Excite@Home Plays Video on High Speed, CNET.COM NEWS, June 26, 2000, at http://Singapore.cnet.com/news/2000/06/27/20000627t.htm.

48. Id.

49. Daniel Roth, Surprise! Yahoo Goes Broadband: Yahoo Has No Megamerger like AOL/Time Warner or Excite@Home, FORTUNE, May 29, 2000, at 182, 190.

50. See Yahoo! Unveils Yahoo! FinanceVision, the First Live Financial Network to Originate from Silicon Valley, BUSINESS WIRE, Mar. 13, 2000, at http://docs.yahoo.com/docs/pr/release $486 . h t m$.

51. Roth, supra note 49 , at 192.

52. Corey Grice \& Jim Hu, Lycos, Yahoo Step Back From Ambitious Broadband Plans, CNET.COM NEWS, May 1, 2000, at http://news.cnet.com/news/0-1005-2001779432.html. 
Further, new entrants face significant entry costs, while entrenched competitors benefit from the low marginal costs associated with the distribution of existing content. It is therefore important to ask whether, given these market conditions, other broadband portals could step in to fill the supply shortfall should AOL decide to limit distribution of its service or content. In such a situation, competing content providers could either expand their production to make up for AOL's shortfall or, if market conditions would permit, raise the price of their products in response to the decrease in supply. The former outcome-boosting production-would likely defeat AOL Time Warner's foreclosure effort and restore the benefits of competition to consumers; the latter-raising price-would likely harm consumers by allowing remaining broadband portals to extract a greater share of surplus.

To determine whether unaffiliated broadband portals would raise their prices rather than expand output in response to the shortage of content, Professors Riordan and Salop ask whether the competitors' equally costeffective capacity is constrained. ${ }^{53}$ As we discussed earlier, the near-zero marginal cost of distributing existing broadband content suggests that none of the equally efficient content providers would be capacity constrained. Whether unaffiliated content providers could easily produce new broadband content in response to an increase in the price of AOL content is less certain, given the significant barriers to entry in the market for content production.

We believe, on this basis, that it would be difficult for unaffiliated broadband portals to expand output by producing new content in the short run. ${ }^{54}$ The reason, as we demonstrate in the following section, is that competing portals lack direct access to cable customers as a result of the cable provider's strategy of tying together the sale of broadband transport and portal services. Therefore, .competing portals would not likely reach enough customers through competing conduits to achieve the scale required to create new marquee content.

Perhaps a more relevant question for addressing the supply response is whether rival broadband content providers could replicate AOL Time Warner's broadband content. For those consumers who insist on having

53. Riordan \& Salop, supra note 32 , at 533.

54. In the next step of the analysis, one must determine the manner in which the competitive effect of input-level discrimination will manifest itself. According to Professors Riordan and Salop, input prices will rise if the structure of the market of nonforeclosed rival sellers is "conducive to coordinated pricing." Id. We feel that the market structure presented in Table 1 is sufficiently concentrated to allow for the possibility of coordinated behavior. 
access to any part of AOL Time Warner's content portfolio-a substantial number given AOL's unrivaled customer base-a foreclosed DSL provider, for example, will not serve as an acceptable substitute. To the extent that the AOL Time Warner's broadband content represents marquee broadband content-AOL ranked first in unique users of its content in a survey conducted in June $2000^{55}$ - rival content providers will not be able to fill the void in a way that maintains the relative attractiveness of foreclosed conduits. Hence, by limiting the supply of broadband content to rival conduits, conduit discrimination by AOL Time Warner would likely place DSL providers and other foreclosed conduits at a significant competitive disadvantage.

\section{Availability of Substitute Broadband Transport Services for Broadband Consumers}

The second condition necessary for a foreclosure strategy to succeed is that customers cannot readily switch to nonforeclosed competitors: "Competition from other downstream producers whose costs are not raised and demand substitution to other products may prevent the downstream division of the integrated firm from leading prices upward." are several factors to consider in determining the likely response of consumers in the event of a downstream or input price increase, including the availability of substitute broadband access products, product differentiation in the output market, and the magnitude of the increase in rivals' costs. $^{57}$

Substitute broadband transport products exist but are not embraced to the same extent as cable modem service. At the end of 1999, cable modems enjoyed a 73 percent share of the residential broadband transport market. Table 2 shows the shares of the residential broadband transport market at the end of 1999 .

55. According to Media Metrix's May 2000 Internet survey, 55,588,000 of the $76,349,000$ unique Web users $(72.8 \%)$ visited one of AOL's Web properties. Press Release, Media Metrix, Inc., Top Digital Media/Web Properties in the U.S. Home Only (July 20, 2000) at http://www.mediametrix.com/press/releases/20000720.jsp.

56. Riordan \& Salop, supra note 32 , at 539.

57. Id. at 539-45. 
Table 2: Residential Broadband Transport Subscribers at June 2000 ${ }^{\mathrm{a}}$

\begin{tabular}{l|l|l}
\hline Provider & $\begin{array}{l}\text { Subscribers } \\
\text { (millions) }\end{array}$ & $\begin{array}{l}\text { Share } \\
\text { (percent) }\end{array}$ \\
\hline Cable modem & 2.179 & 69.8 \\
DSL & 0.875 & 28.1 \\
Satellite and Fixed Wireless & 0.064 & 2.1 \\
TOTAL & 3.120 & 100.0 \\
\hline
\end{tabular}

Source: Press Release, FCC, Federal Communications Commission Releases Data on High-Speed Data for Internet Access, at 8, tbl.3 (Oct. 31, 2001), available at http://www.fcc.gov/Bureaus/Common_Carrier/Reports/FCC-State_Link/IAD /hspd1000.pdf.

${ }^{\text {a }}$ Includes small business subscribers.

The table makes it clear that by June 2000 the ratio of cable modem subscribers to DSL subscribers was 2.5 to 1 . As recently as August 2000, cable modems maintained a commanding 68.2 percent of the broadband access market. ${ }^{58}$ Using the subscriber shares in Table 2 as representative of a typical local geographic market, ${ }^{59}$ we find the Herfindahl-Hirschman Index ("HHI") for residential broadband access to be 5,673. ${ }^{60}$ According to the Horizontal Merger Guidelines, the above index suggests that residential broadband access markets are "highly concentrated."

Although cable modems enjoy a relatively high percentage of subscribers, they nonetheless face technical impediments. For example, "cable users regularly complain about slowdowns caused by too many people on the system." 62 Depending on the number of users in a neighborhood that are logged on, speeds can vary widely hour by hour. To alleviate that

58. Eric Ladley, DSL Threatens Excite@Home's Dominance, BROADBAND NETWORKING NEWS, Aug. 29, 2000, at 6 (3 million cable subscribers versus 1.4 million DSL subscribers).

59. If cable maintains a 73 percent share of the high-speed residential Internet market nationwide, then on average, a local cable provider will maintain a share of 73 percent of the high speed residential Internet local geographic market.

60. To our knowledge, data describing residential broadband access market shares by geographic area are not available.

61. Dep't of Justice \& FTC, Horizontal Merger Guidelines 1992, § 1.5.

62. Dave Gussow, Full Speed Ahead Series: Tech-Times, St. PeTERSBurg Times, Aug. 28, 2000, at 11E. 
problem, several cable firms prevent users from hosting websites or other commercial uses on residential cable connections. ${ }^{63}$ In addition, not all cable companies have upgraded their equipment to offer the service. For example, AT\&T cable Internet access is not yet available in large portions of downtown San Francisco. ${ }^{64}$ Finally, cable subscriber growth is limited because of unexpected parts shortages at Motorola and other equipment manufacturers. For example, Excite@ Home blamed its 10 percent drop in growth on a temporary interruption in the supply of cable modems. ${ }^{65} \mathrm{Cer}-$ tainly those problems, if not addressed adequately, would undermine a cable firm's ability to discriminate against unaffiliated content and conduit providers.

DSL represents the greatest potential source of pricing discipline for cable firms. Hence, the most likely target of conduit foreclosure by AOL would be a DSL provider. Because AOL owns a share of the satellitebased broadband enterprise, AOL will not likely foreclose its own affiliate. ${ }^{66}$ As a result, if successful, broadband customers will not have the option of switching to a nonforeclosed DSL provider. Even if they could switch, DSL providers are to some extent at a disadvantage in getting to market with respect to cable firms, and conduit discrimination by AOL would threaten to derail DSL deployment even further.

DSL deployment is constrained by technical impediments. Beginning in the 1970s, local exchange carriers began using a new type of loop-a digital loop carrier ("DLC") - to reduce the cost of building new central offices to service growing suburbs and more densely populated urban areas. ${ }^{67}$ DLCs rely on digital transmission between the local loop and the central office. As a result, DSL service cannot be supported by DLCs be-

63. Id. That problem is not unique to cable providers, however, as many DSL providers have experienced similar complaints. For example, in August 2000 SBC was sued by residents of Nueces County, Texas, who claimed that SBC promised connections of up to $384 \mathrm{kbps}$ but actually limited connections to $128 \mathrm{kbps}$ for customers that used email and newsgroups. See Eric Ladley, supra note 58.

64. See Todd Wallack, ExciteAtHome Does an About-Face on DSL, S.F. CHRON., Feb. 25, 2000, at B1 (explaining that cable lines are "scarce in many downtown business districts.").

65. Cable Modems Retain Market Lead but DSL is Growing Faster, COMM. DAIll, Aug. 2, 2000.

66. Under its agreement with Hughes, AOL made a $\$ 1.5$ billion investment in a General Motors equity security, which carried a 6-1/4\% coupon rate that was automatically convertible into GM Class $\mathrm{H}$ common stock at a 24 percent premium in three years. AMERICA ONLINE, INC., 2000 SEC FORM 10-K.

67. For a discussion of the difference between "old" and "new" loops, see STRATEGIS GROUP, HIGH-SPEED INTERNET ACCESS [1998-1999] 47 (1998) [hereinafter HIGHSPEED ACCESS]. 
cause DSL requires transceiver-to-transceiver signal consistency. To provide DSL over DLCs, the carrier must install a digital subscriber line access multiplier ("DSLAM") termination at the DLC. That additional investment may impede DSL's ability to compete with cable-based broadband Internet access:

Although there are other solutions to the DLC problem besides RAM deployment, additional capital expenditures to overcome this problem cannot yet be avoided. This raises the cost of DSL deployment, and consequently, DSL service. The problem is exacerbated by the fact that DLCs have their greatest penetration in newer suburban subdivisions. These households are likely to be potential high-speed Internet users. ${ }^{68}$

DLCs could limit DSL deployment in regions where DLCs have been used extensively, such as the Southeast and Midwest. ${ }^{69}$ For example, almost 40 percent of BellSouth customers are connected through DLCs. ${ }^{70}$ Even though such impediments should eventually be overcome, there will be significant incremental costs incurred by DSL providers to serve those customers.

Even in geographic markets where customers are connected with "old" loop technology, DSL deployment is constrained by different technical impediments. DSL is sensitive to the distance that transmissions must travel between the home and central office. According to a study commissioned by the Competitive Broadband Coalition, DSL in its current form faces "an absolute limit of approximately 18,000 feet for the copper segment." "71 That impediment will severely limit DSL's ability to impose price discipline on cable-based providers of Internet access in areas located several miles from the central office. For example, nearly 35 percent of all GTE telephone customers (and hence potential broadband customers) are beyond 18,000 feet of a central office. ${ }^{72}$

Given the more severe impediments to DSL than to cable modems, the relevant antitrust question is whether there currently exists any alternative

68. Id. at 49 .

69. Id. at 4 .

70. Id. at 50. Strategis reports that 15 percent of Bell Atlantic's customers are connected through DLCs. Id.

71. LeE L. Selwyn et al., Building a Broadband America: The CompettTive KEYS TO THE FUTURE OF THE INTERNET 61 (1999) (prepared for the Competitive Broadband Coalition).

72. See Petition of GTE Service Corp. at app. C, II 10, In re Applications for Consent to Transfer Control of MediaOne Group, Inc. to AT\&T Corp., 15 F.C.C.R. 9816 (2000) (No. 99-251) (declaration of Dale E. Veeneman \& Everett H. Williams). 
broadband transport technology that could undermine AOL's ability to foreclose DSL. Satellite-based high-speed Internet service is not currently a close substitute to cable-based Internet access because, unlike cable systems, it provides high-speed connection in only one direction, from the satellite to the user's computer. Current subscribers of DirecTV's satellite broadband network must upload information over standard (narrowband) telephone lines at maximum speeds of $56.6 \mathrm{Kbps}^{73}$ A fully two-way broadband system over satellite (known as Spaceway) will not become available until $2002 .^{74}$

Due to its direct ownership interest in DirecPC, the broadband Internet service provided by DirecTV, ${ }^{75} \mathrm{AOL}$ is unlikely to discriminate against DirecTV, a major satellite provider, at the input level. In this narrow sense, DirecPC would represent a "nonforeclosed competitor" to a merged AOL Time Warner with the potential to undermine AOL's foreclosure strategy ${ }^{76}$ However, because the satellite connection currently amounts to an inferior substitute to cable, and because AOL can influence the price of DirecPC, the existence of this nonforeclosed competitor would not by itself undermine AOL Time Warner's ability to engage in conduit discrimination against DSL providers. Hence, there are no downstream rivals that could discipline AOL Time Warner's conduit foreclosure tactics and broadband end users could not frustrate AOL Time Warner's efforts at conduit discrimination by turning to a significant nonforeclosed broadband conduit. Thus, we conclude that the competitive conditions in the broadband content market are such that any attempt by AOL to engage in conduit discrimination would result in higher costs and a lower market share for DSL and other broadband conduits.

73. Press Release, Hughes Elecs. Corp., America Online and Hughes Electronics Form Strategic Alliance to Market Unparalleled Digital Entertainment and Internet Services (June 21, 1999), http://www.directv.com/press/pressdel/0,1112,198,00.html.

74. Id.

75. See HUGHES ELECTRONIC CORPORATION, 2000 SEC FORM 10-K.

76. Concerned that AOL would control substitute broadband conduits, consumer groups have called for AOL to divest itself of its partial ownership in DirecPC. Petition to Deny of Consumers Union, Consumer Fed'n of Am., Media Access Project, and Center for Media Education at 2, In re Applications for Consent to the Transfer of Control of Licenses and Section 214 Authorizations by Time Warner Inc. and Am. Online, Inc., Transferors, to AOL Time Warner, Inc., Transferee, 2001 F.C.C. LEXIS 432 (Jan. 22, 2001) (No. 00-30). Ironically, AOL's ownership of the satellite conduit protects against the type of discrimination at issue here. Such a divestiture would only exacerbate our concerns, as the set of "nonforeclosed competitors" would become empty. Unless AOL were to acquire a share of the DSL conduits (an unlikely event), that remedy would require additional protections against conduit discrimination. 


\section{B. Post-Merger Ability to Engage in Content Discrimination}

To determine whether AOL would have the ability to engage in content discrimination - that is, discrimination against rival content providers seeking to reach AOL's customers-we must evaluate two similar competitive effects. First, we analyze whether upstream content rivals could reach a sufficiently large set of customers through alternative conduits. Second, we determine whether foreclosure would reduce the operating scale of an upstream rival to below minimum viable scale or increase its marginal costs.

\section{Availability of Alternative Broadband Customers}

Professors Riordan and Salop explain that content discrimination may simply cause a "realignment in supplier relationships" having "little net effect on the sales of the input suppliers," but content discrimination may harm rivals in cases where "input suppliers are unable to replace the lost sales." ${ }^{\text {"77 }}$ Stated differently, one must determine whether any other broadband conduit has a customer base large enough to restore a content provider's lost revenues from cable customers. As described in Part A.2 above, the availability of alternative broadband conduits is limited. According to a January 2000 McKinsey study, as of the end of 1999, DSL providers could only address 44 percent of U.S. households. ${ }^{78}$ Even in areas where DSL is available, the existence of significant switching costs (for example, the time and complexity of switching and the purchase of a DSL modem) would necessitate a large sense of content-specific loyalty to induce a cable customer to switch to DSL. ${ }^{79}$ "Different requirements for inside wiring, different terminal equipment, nonrefundable connection charges, different computer set-ups in many cases are among the factors that can easily push the physical cost of switching between cable and DSL [where both are available] up to $\$ 600 . " 80$

Professors Riordan and Salop conclude by pointing out that the "loss of the integrated firm as a customer is less significant if that firm's pre-

77. Riordan \& Salop, supra note 32, at 554.

78. MCKINSEY STUDY, BROADBAND! 27 (released Jan. 2000).

79. To the extent that customers are plagued by the fallacy of sunk costs, they might erroneously take the cost of the cable modem into the decision to switch to DSL as well. This may explain why consumers are hesitant to switch to DSL once they have purchased a cable modem. See, e.g., Kevin Featherly, Report: Cable's Broadband Lead Over DSL Remains Solid, NEwSBYTES, Apr. 19, 2000, at http://www.newsbytes.com/News/00/ 147760.html.

80. François Bar et al., Access and Innovation Policy for the Third-Generation Internet, 24 TELECOMM. POL'Y 489, 502 (2000). 
merger purchases from unintegrated firms is a small share of its available sales base." ${ }^{\prime 1}$ As depicted in Table 2, cable's broadband transport market share in June 2000 was roughly 70 percent. Hence, according to their framework, it is unlikely that a sufficient number of alternative broadband customers would be available through competing conduits to save content and portal competitors foreclosed from AOL Time Warner's system.

\section{Minimum Viable Scale and the Marginal Cost of Broadband Content}

Given the existence of economies of scale in the broadband portal market, ${ }^{82}$ it is conceivable that a broadband portal would "exit from the market if the foreclosure drives it below minimum viable scale ("MVS") at premerger prices." ${ }^{, 83}$ In the short lifetime of the broadband content industry, several notable broadband content providers have exited the industry or are contemplating exit. ${ }^{84}$ Even where the foreclosed input supplier does not fall below MVS, its ability or incentives to compete may be reduced if its marginal costs rise: "In particular, a reduced customer base may reduce the incentives of the foreclosed firm to invest in cost reduction, product quality, or other non-price product dimensions." ${ }^{15}$ This effect would be particularly acute because broadband content providers need to spread development costs over a larger customer base, ${ }^{86}$ and the denial of access to AOL's customer base would undermine such efforts. A merged AOL Time Warner is thus unlikely to face any significant market check on its ability to discriminate against outside content. Having looked at the ability to discriminate, we now turn to its incentives.

\section{AOL TIME WARNER'S INCENTIVES TO ENGAGE IN CONDUIT OR CONTENT DISCRIMINATION}

In this Part we provide a framework to evaluate whether a foreclosure strategy that involves either conduit discrimination, content discrimination, or both, is likely to be profitable for AOL Time Warner. We rely on

81. Riordan \& Salop, supra note 32, at 554.

82. See supra Part IV.A.1.

83. Riordan \& Salop, supra note 32 , at 554-55.

84. Oreskovic, supra note 45 (noting the exit of Digital Entertainment Network and Pixelon).

85. Riordan \& Salop, supra note 32, at 555.

86. See, e.g., Declaration of Janusz A. Ordover \& Robert D. Willig at 20, In re Application for Consent to Transfer Control of MediaOne Group, Inc. to AT\&T Corp., 15 F.C.C.R. 9816 (2000) (No. 99-251) (explaining that "[i]f new entrants are to compete with incumbent LECs and leading Internet and online service providers, they also must have the opportunity to serve a large customer base"). 
theoretical literature in the economics of industrial organization that examines the incentives to foreclose competition through discriminatory practices and the conditions under which a company could sustain such foreclosure strategies in the long run (that is, whether foreclosure is profitable in equilibrium). We briefly review that literature and then apply the theory to analyze the proposed merger of $\mathrm{AOL}$ and Time Warner.

\section{A. Theoretical Models of Foreclosure}

Professors Janusz Ordover, Garth Saloner, and Steven Salop were the first economists to model formally the foreclosure calculus in a gametheoretic context. ${ }^{87}$ In their model, the refusal to supply inputs by the integrated firm to the rival of its downstream division (conduit discrimination) implies that the remaining upstream supplier will face less competition in serving the foreclosed downstream firm. ${ }^{88}$ If the nonaffiliated upstream supplier raises its price to the rival downstream firm, the downstream rival will respond by raising the prices it charges to end users. Hence, the diminished upstream competition caused by conduit foreclosure increases the downstream market share of the integrated firm and supports a higher downstream price and increased profits. ${ }^{89}$ Because the foreclosure equilibrium involves higher prices for all downstream firms without any offsetting efficiency gains, overall social welfare (and, more specifically, consumer welfare) decreases.

Building on this work, Professors Jeffrey Church and Neil Gandal have investigated foreclosure while treating the downstream product as a system composed of hardware (supplied by the downstream provider) and its complementary software (supplied by the upstream provider) ${ }^{90}$ In the Church-Gandal framework, the value of the system increases as the variety of the available software grows. Foreclosure involves a decision to make one's software incompatible with rival hardware technologies,

87. Janusz A. Ordover et al., Equilibrium Vertical Foreclosure, 80 AM. ECON. REV. $127,133-42(1990)$.

88. Their model assumes two upstream firms and two downstream firms. Id. at 131 . The results can be replicated with additional firms.

89. Despite the fact that there is some degree of competition at both the upstream and downstream levels, an equilibrium with foreclosure can occur if: (1) the downstream firms' revenues are decreasing in the price of the input (that is, if the price of the final good does not increase as fast as the quantity demand of the final good falls); and (2) the unintegrated upstream firms do not have sufficient incentive to raise prices to the unintegrated downstream firms (if otherwise, the nonintegrated downstream firms will lose so much share that they will have an incentive to merge with upstream firms).

90. See Jeffrey Church \& Neil Gandal, Systems Competition, Vertical Merger, and Foreclosure, 9 J. ECON. \& MGMT. STRATEGY 25, 25 (2000). 
which again amounts to conduit discrimination. Against the backdrop of vertical integration in the cable television industry, Church and Gandal "expect that conflicts over access to content will arise with the development of the information highway and competition between alternative technologies and vendors." ${ }^{\text {"1 }}$ The authors demonstrate that foreclosure by a single firm, when the other firm does not retaliate in kind, can occur if either: (1) the hardware products are highly differentiated and the marginal value of software variety is small; or (2) the hardware products are not highly differentiated. The authors identify both direct and indirect effects of foreclosure on hardware (downstream) profits: "The direct effect is the increase in demand from the differential created in software availability for the two hardware systems. The indirect effect is the associated change in hardware pricing. The increase in demand can provide the foreclosing firm with incentives to charge higher prices for its hardware. $" 92$

After noting that there appears to be little product differentiation among the hardware products, Church and Gandal conclude with the following policy implication: "consent decrees that require integrated 'hardware/software' firms to make software available on a nondiscriminatory basis for other hardware technologies might prevent foreclosure that would lead to socially inefficient standardization on one of the platforms." 93

With this background, we can now spell out our concern that a vertically-integrated broadband transport and portal provider would have an incentive to pursue two foreclosure strategies: (1) engage in conduit discrimination by withholding its service over rival conduits or by placing marquee content solely within a "walled garden"; or (2) engage in content discrimination by denying, limiting, or degrading customers' access to unaffiliated content. We discuss the incentives to engage in each strategy below, noting that according to Church and Gandal, the decision to foreclose is straightforward: "The profitability of foreclosure depends on the trade off between lost software profits (from not supplying the competing system) and increased hardware profits (from the increase in demand and potentially the increase in hardware price). Foreclosure has both a direct and indirect effect on hardware profits." 94 Indeed, Professors Riordan and Salop echo that logic:

91. Id. at 27.

92. Id. at 28 .

93. Id. at 47 .

94. Id. at 28. 
The impact on lost input sales is relevant to evaluating the incentives for the integrated firm to attempt input foreclosure. Even if an input price increase raises rivals' costs, that alone does not prove that the price rise is profitable to the integrated firm. The upstream division may lose so many input sales that the input market revenue lost exceeds the higher revenue on input sales retained plus the increased profits to the downstream division. ${ }^{95}$

In the following sections, we analyze each of those possible effects in the market for residential broadband access.

\section{B. Post-Merger Incentives to Engage in Conduit Discrimination}

\section{Necessary Conditions for Conduit Discrimination}

Conduit discrimination is costly, as a firm engaging in conduit discrimination will forego revenues from content distribution over foreclosed platforms. There are potentially countervailing benefits, however, because with conduit discrimination, customers will perceive the cable conduit as more valuable. This, in turn, will increase the demand for cable transport relative to other forms of transport. Hence, a cable broadband provider will engage in conduit discrimination if the gain from additional access revenues from broadband users offsets the loss in content revenues from narrower distribution.

What determines whether conduit discrimination will be profitable? Simply put, if a cable broadband transport provider that controls particular content only has a small fraction of the national cable broadband transport market, then that provider would have little incentive to discriminate against rival broadband transport providers outside of its cable footprint. ${ }^{96}$ The intuition is straightforward: out-of-franchise conduit discrimination would inflict a loss on the cable provider's content division, while out-ofregion cable providers would be the primary beneficiaries of harm done to non-cable competitors. To capture the gains from such discrimination, the vertically integrated cable provider must have a cable footprint in which to distribute its broadband portal service, either through direct ownership or through an arrangement to share the benefits of foreclosure with other cable providers.

Borrowing from the model of Church and Gandal, it is possible to appreciate the range of parameters under which a merged AOL Time Warner

95. Riordan \& Salop, supra note 32 , at 532.

96. A cable provider's footprint refers to those areas in the country where the cable provider currently offers cable service. 
will have an incentive to engage in conduit discrimination. We define the following variables:

$k=$ AOL Time Warner share of homes served by cable providers nationwide or "conduit footprint" (equal to 0.19$)^{97}$

$t=$ AOL Time Warner in-region residential broadband access share (equal to 0.73$)^{98}$

$p=$ AOL Time Warner monthly transport-Internet service price per cable subscriber (equal to $\$ 40.00)^{99}$

$\rho=$ AOL Time Warner monthly content/advertising revenues per broadband cable subscriber (equal to $\$ 23.62$ ) ${ }^{100}$

$q=\mathrm{AOL}$ Time Warner residential DSL customer share (assumed equal to 0.30 )

$o=$ AOL Time Warner monthly access price for DSL subscribers (equal to $\$ 21.95)^{101}$

A combined AOL Time Warner would secure broadband revenues from at least three sources. The first is in-region broadband transport and portal revenues from cable customers, $k t(p+\rho)$. The second source is the in-region portal and content revenues from customers served by alternative conduits, $k(1-t) q(o+\rho)$. The third source of revenue comes from out-of-region portal and content revenues from customers served through non-cable conduits, $(1-k)(1-t) q(o+\rho)$.

While it is theoretically possible to discriminate selectively in the distribution of content, ${ }^{102}$ we assume conservatively that conduit foreclosure results in lost content sales across the nation, whereas increasing conduit sales and higher conduit prices generate revenues only within-region. Cur-

97. This is the percentage of homes served by the Time Warner cable system. HIGH SPEED ACCESS, supra note 67, at 142 (Time Warner served 19.2 million homes.).

98. Based on nationwide average of cable modems' share of residential broadband access market. STRATEGIS GROUP, CABLE TRENDS (2000). In-region is defined as those parts of the country where AOL Time Warner is offering cable service. Out-of-region is the complement of in-region.

99. AT HOME CORP., 1999 SEC FORM 10-K, at 6.

100. Id. @Home's content and advertising revenues were chosen over AOL's content and advertising revenues because (1) @Home's revenue reflects the revenue streams associated with broadband content and (2) AOL's revenues contain some influence of network effects owing to its large share of the narrowband residential market.

101. Ken Feinstein, The AOLization of America: A Perspective, CNET.COM NEws, Apr. 19, 2000, at http://www.cnet.com/techtrends/0-1544320-7-1708289.html.

102. AOL could, for example, refuse to market its Internet service in-region over DSL or refuse to interconnect with certain DSL providers. 
rently, DSL is an open system (which by law must interconnect with rival ISPs) whereas rival cable systems are closed (that is, a rival cable system would presumably continue to reject AOL as its broadband access provider). Consequently, if AOL engaged in conduit discrimination, it would forego its monthly access fee for DSL customers that would have subscribed to AOL inside and outside its conduit footprint.

The formal analysis that follows balances the merged firm's three economic interests that flow from the three revenue streams. To begin, let $\Pi_{U}$ be the expected monthly revenue per broadband subscriber when AOL does not engage in conduit discrimination. Then,

$$
\text { (1) } \begin{aligned}
\Pi_{\mathrm{U}} & =[k t(p+\rho)]+[k(1-t) q(o+\rho)]+[(1-k)(1-\mathrm{t}) q(o+\rho)] \\
& =k t(p+\rho)+(1-t) q(o+\rho) \\
& =(.19)(.73)(\$ 40.00+\$ 23.62)+(1-.73)(.30)(\$ 21.95+\$ 23.62) \\
& =\$ 8.82+\$ 3.69=\$ 12.51
\end{aligned}
$$

Now define $\Pi_{\mathrm{F}}$ to be the expected monthly revenue per broadband subscriber when AOL engages in conduit discrimination. Also, let $t_{\mathrm{F}}$ equal AOL Time Warner's in-region broadband access share with input discrimination, and $p_{\mathrm{F}}$ be the corresponding monthly transport portal service price. We expect conduit discrimination to eliminate all out-of-region transport and content sales, $[(1-k)(1-t) q(o+\rho)]$, as well as in-region content sales to non-cable broadband conduit providers, $[k(1-t) q(o+\rho)]$. It follows, therefore, that,

(2) $\Pi_{\mathrm{F}}=k t_{\mathrm{F}}\left(p_{\mathrm{F}}+\rho\right)$

$$
=0.19 t_{\mathrm{F}}\left(p_{\mathrm{F}}+\$ 23.62\right)
$$

As the theory of vertical foreclosure suggests, conduit discrimination will, in general, allow AOL Time Warner to increase both its broadband transport share and its transport price in-region due to AOL Time Warner's now relatively richer content offering. In particular, conduit discrimination increases in-region market share because end users must choose the vertically-integrated producer's conduit to access its content. ${ }^{103}$

103. See, e.g., Church \& Gandal, supra note 90 , at 39 (explaining that "as expected, the effect of foreclosure [of a downstream rival] is an increase in market share. Indeed, if the variety advantage is large enough relative to the degree of hardware differentiation, then a standardization equilibrium results and all consumers purchase [the foreclosing firm's] technology."). 
We expect, therefore, that $t_{\mathrm{F}} \geq 73$ percent and $p_{\mathrm{F}} \geq \$ 40$. Put differently, conduit foreclosure has a direct effect on conduit profits, caused by the increase in content demand that results from the differential in content availability over cable modems and DSL. It also has an indirect effect on conduit profits, caused by the change in access pricing that results from an increase in demand for cable modems.

As we pointed out earlier, however, conduit discrimination will lead to a loss in access and content-related revenues out-of-region. Clearly, for foreclosure to be profitable, in-region revenue increases must outweigh these out-of-region losses. Formally, discrimination will be profitable if $\Pi_{\mathrm{F}}$ is greater than or equal to $\Pi_{\mathrm{U}}$. An equivalent condition is

\section{(3) $0.19 t_{\mathrm{F}}\left(p_{\mathrm{F}}+\$ 23.62\right) \geq \$ 12.40$}

We have solved for the access price-market share combinations that would allow AOL to earn equal profit whether or not it engaged in conduit discrimination (namely, $t_{\mathrm{F}}$ and $p_{\mathrm{F}}$ such that $\Pi_{\mathrm{U}}=\Pi_{\mathrm{F}}$ ). Figure 1 plots those combinations, shown as the zero-profit frontier, given AOL Time Warner's current nationwide conduit footprint of 19 percent.

Figure 1: Necessary Conditions for AOL Time Warner to Engage in Conduit Discrimination

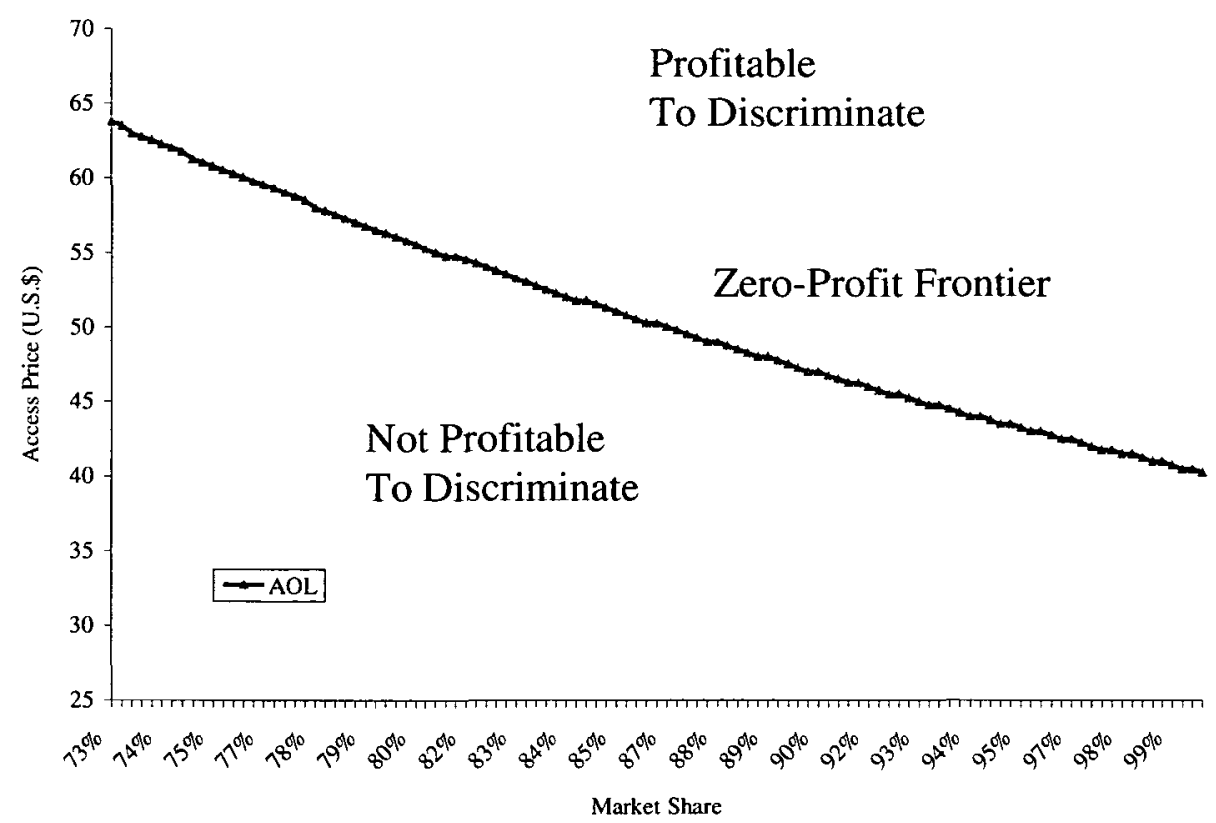


Figure 1 shows, for example, that even if AOL Time Warner increases its access price for cable customers by $\$ 10$ per month to $\$ 50$ per month, AOL Time Warner would need to capture an additional 14 percent of its in-region residential broadband access market $(t)$ to make conduit discrimination profitable. Hence, given its current limited conduit footprint $(k)$, it is unlikely that AOL Time Warner will engage in significant widespread conduit discrimination outside of its cable franchise territory.

We have assumed that the conduit discrimination strategy would be imposed on a nationwide basis. Our concern with the possibility of conduit discrimination would increase significantly were AOL Time Warner to selectively implement such a strategy only within its own cable footprint. In this case, there would be no lost out-of-region revenues making discrimination substantially more profitable. More generally, the ability to apply a discriminatory strategy differentially within and without the AOL Time Warner cable footprint is likely to increase substantially the profitability of conduit discrimination. Such a strategy is easy to imagine. Within its cable franchise, AOL Time Warner could, for example, steer customers to cable transport by representing that its portal service works best when delivered over cable. Such a strategy would undoubtedly be profitable, since it would not result in lost revenues. Customers insistent on purchasing DSL could do so and still receive AOL Time Warner's portal service; customers without a strong preference for a particular transport platform could readily be driven to purchase cable transport.

Beyond this prospect of unilateral conduit discrimination, our framework is also useful in studying horizontal relationships between two (or more) cable providers. Suppose that AOL Time Warner and AT\&TMediaOne entered into an agreement that effectively pooled their cable distribution footprints. Given AT\&T's cable footprint of 30 percent (including its MediaOne and TCI properties), ${ }^{104}$ the combined cable distribution footprint of AOL and AT\&T would be approximately 49 percent $(k=$ 0.49 ). Figure 2 plots the profit available to AOL from engaging in conduit discrimination as the size of its cable distribution footprint increases.

104. HIGH-SPEED ACCESS, supra note 67, at 140-41 (TCI had 22 million homes passed and MediaOne had 8.4 million homes passed). 
Figure 2: Effect of an Increase in the Size of the Conduit Footprint on the Profitability of Conduit Discrimination



Note: Assumes in-region cable broadband market share of 78 percent and transport/Internet service price of $\$ 58$ per month (a price that would make discrimination just profitable for a cable firm with $k=19$ percent).

The total profit line, which represents the monthly revenues across all AOL Time Warner broadband subscribers from engaging in conduit discrimination (the appropriate units of measurement are on the left-hand vertical axis), shows that AOL Time Warner would earn higher profits from conduit discrimination if it increased the size of its distribution footprint. ${ }^{105}$ The total profit per homes passed curve, which represents the total profit from discrimination divided by the number of homes passed by AOL Time Warner cable systems (the appropriate units of measurement are on the right-hand axis), indicates that the monthly gains from discrimination on a per home basis also grow with the size of its cable distribution footprint. Thus, conduit discrimination will be more profitable for AOL Time Warner if it negotiates an access deal with AT\&T. Indeed, Figure 2 shows that even on a proportional basis, the profit associated with conduit

105. Total profit is defined as the product of the differential profit per broadband subscriber and the current number of nationwide broadband subscribers $(=1,980,000)$. 
discrimination is an increasing function of the size of AOL Time Warner's cable distribution footprint. Proposition 1 summarizes this general point.

Proposition 1: An increase in the size of a cable company's footprint will increase its incentive to engage in conduit discrimination.

Proof: With conduit discrimination, $t_{\mathrm{F}} \geq t$ and $p_{\mathrm{F}} \geq p$. The change in profit from engaging in conduit discrimination is

$$
\text { (4) } \begin{aligned}
\Delta \Pi & =\Pi_{\mathrm{F}}-\Pi_{\mathrm{U}}=k t_{\mathrm{F}}\left(p_{\mathrm{F}}+\rho\right)-k t(p+\rho)-(1-\mathrm{t}) q(o+\rho) \\
& =k\left[t_{\mathrm{F}}\left(p_{\mathrm{F}}+\rho\right)-t(p+\rho)\right]-(1-\mathrm{t}) q(o+\rho)
\end{aligned}
$$

The derivative of the change in profit with respect to the size of the footprint is therefore

(5) $\partial \Delta \Pi / \partial k=t_{\mathrm{F}}\left(p_{\mathrm{F}}+\rho\right)-t(p+\rho)$,

which is greater than or equal to zero for all $t_{\mathrm{F}} \geq t, p_{\mathrm{F}} \geq p .^{106}$

2. Example of Conduit Discrimination in the Cable Television Industry

This risk of conduit discrimination is real. Indeed, discrimination by cable operators against alternative conduits, such as wireless cable operators, has prompted regulation in the past. For example, an FCC study found that wireless cable operators paid 36.4 to 78.6 percent more per subscriber for six cable network services than did cable operators. ${ }^{107}$ Section 628(c) of the 1992 Cable Act instructed the FCC to adopt regulations that would, among other things, prevent undue influence by cable operators on actions by affiliated program vendors related to the sale of programming to unaffiliated distributors. ${ }^{108}$ In April 1993, the FCC issued rules that lowered the evidentiary burden for programming-access complainants and prohibited program exclusivity arrangements. ${ }^{109}$ In a related antitrust matter, the DOJ obtained a settlement with the Primestar direct broadcast satellite ("DBS") partners to make affiliated programming such as $\mathrm{HBO}$, Cinemax, and MTV available to DBS and other non-cable services at non-

106. More generally, the profitability of conduit discrimination will increase whenever (5) is positive; this condition will also hold for a range of values when $t_{\mathrm{F}}<t$.

107. In re Competition, Rate Regulation, and the Commission's Policies Relating to the Provision of Cable Television Service, 5 F.C.C.R. 362, tbl. XI (1990).

108. In re Implementation of Sections 12 and 19 of the Cable Television Consumer Protection and Competition Act of 1992, 8 F.C.C.R. 3359, ITI 3, 3(1) (1993).

109. Id. Tापा 3(3), 9. 
discriminatory prices. ${ }^{10}$ As will be explained below, merger conditions are likewise required here to eliminate the risk of conduit discrimination.

\section{Post-Merger Incentives for Content Discrimination \\ 1. Necessary Conditions for Content Discrimination}

To complete our analysis, it is important to consider whether a combined AOL Time Warner would have an incentive to engage in content discrimination by blocking its customers' access to unaffiliated content. For example, to insulate Spinner (AOL's Internet radio service) and Time Warner's music portfolio from competition, AOL could refuse to distribute music from competing record companies. ${ }^{111}$ This form of discrimination would enhance the position of AOL's affiliated content providers in the national market by denying unaffiliated content providers critical operating scale and insulating affiliated content providers from competition. Thus, content discrimination would allow AOL Time Warner to earn extra revenues from its own portal customers who would have fewer opportunities to interact with competing outside content.

The cost of content discrimination is the potential loss in revenue from customers that demand the withheld content. To the extent that cable transport providers compete against DSL and other broadband transport providers, the reduction in revenues from lost customers will be greater. Further, note that content discrimination does not require a complete denial of access to outside content. Nevertheless, even less severe strategies (for example, providing unequal caching treatment to unaffiliated content providers) may inflict some loss on the downstream transport division, because some customers may still prefer to switch transport providers rather than suffer slower access to outside content. Hence, AOL Time Warner will engage in content discrimination if the gain from additional portal, content, and advertising sales offsets the reduction in broadband access revenues resulting from lost broadband subscribers.

To analyze the conditions under which content discrimination would be profitable for AOL Time Warner, we rely on the set of parameters that were defined previously.

110. See United States v. Primestar Partners, 58 Fed. Reg. 33944 (June 22, 1993) (proposed final judgment and competitive impact statement).

111. The AOLization of America: Beyond Microsoft, CNET.COM NEWS, Apr. 19, 2000, at http://www.cnet.com/techtrends/0-1544320-7-1708292.html. AOL could also seek to protect its other content assets, including Digital City, The Knot, MapQuest, and MovieFone. 
$k=$ AOL Time Warner share of homes passed nationwide (equal to 0.19)

$t=$ AOL Time Warner in-region residential broadband access share (equal to 0.73)

$p=$ AOL Time Warner monthly transport-Internet service price per cable subscriber (equal to $\$ 40.00$ )

$\rho=$ AOL Time Warner monthly content/advertising revenues per cable broadband subscriber (equal to $\$ 23.62$ )

$q=$ AOL Time Warner residential DSL customer share (equal to $0.30)$

$o=$ AOL Time Warner monthly access price for DSL subscribers (equal to $\$ 21.95$ )

Content discrimination results in lost in-region access sales, but potentially increasing content and advertising sales across the nation. We assume that AOL considers whether it is profitable to engage in content discrimination independently of its decision to engage in conduit discrimination. ${ }^{112}$ Define $\Pi_{U}$ as the expected monthly revenue per broadband subscriber when AOL does not engage in content discrimination. Then, as before, there are three sources of revenues available to AOL Time Warner:

(6)

$$
\begin{aligned}
\Pi_{U} & =[k t(p+\rho)]+[k(1-t) q(o+\rho)]+[(1-k)(1-t) q(o+\rho)] \\
& =k t(p+\rho)+(1-t) q(o+\rho) \\
& =(.19)(.73)(\$ 40.00+\$ 23.62)+(1-.73)(.30)(\$ 21.95+\$ 23.62) \\
& =\$ 8.82+\$ 3.69=\$ 12.51
\end{aligned}
$$

Next define $\Pi_{F}$ as the expected monthly revenue per broadband subscriber when AOL Time Warner engages in content discrimination, and define $t_{\mathrm{F}}, q_{\mathrm{F}}$, and $\rho_{\mathrm{F}}$ accordingly. To simplify the analysis, we conservatively assume that content discrimination affects content and advertising revenues within-region (by limiting the choices of in-region broadband customers), but has no effect on such revenues outside-of-region. Consequently, we also assume that the merged company's DSL penetration would remain unchanged inside and outside its cable footprint - that is, $q_{\mathrm{F}}$ $=q=0.30$. Then,

112. The two strategies could also be employed simultaneously with the benefits of one strategy reinforcing the incentives to engage in the other. We have not considered the interaction of the two discrimination strategies here. 


$$
\text { (7) } \begin{aligned}
\Pi_{\mathrm{F}}= & {\left[k t_{\mathrm{F}}\left(p+\rho_{\mathrm{F}}\right)\right]+\left[k\left(1-t_{\mathrm{F}}\right) q\left(o+\rho_{\mathrm{F}}\right)\right]+[(1-k)(1-t) q(o+\rho)] } \\
= & .19 t_{\mathrm{F}}\left(\$ 40.00+\rho_{\mathrm{F}}\right)+.19\left(1-t_{\mathrm{F}}\right)(.30)\left(\$ 21.95+\rho_{\mathrm{F}}\right) \\
& +.19(1-0.73)(.30)(\$ 21.95+\$ 23.62)
\end{aligned}
$$

Content foreclosure has a direct effect on content profits-an increase in demand from the fact that rival content producers might not achieve minimum viable scale. It also has an indirect effect-the associated change in content and access pricing due to the increase in demand for its affiliated content. Content discrimination might jeopardize in-region broadband transport market share by antagonizing cable subscribers. Revenue per customer will increase, however, because cable operators can charge higher prices for content and advertising used by the infra-marginal in-region cable customers who do not switch to a competing conduit. Hence, $t_{\mathrm{F}} \leq \mathrm{t}$ and $\rho_{\mathrm{F}} \geq \rho$. Thus, for content discrimination to be profitable, $\Pi_{\mathrm{F}}$ must exceed $\Pi_{U}$ or,

(8) $.19 t_{\mathrm{F}}\left(\$ 40.00+\rho_{\mathrm{F}}\right)+.19\left(1-t_{\mathrm{F}}\right)(.30)\left(\$ 21.95+\rho_{\mathrm{F}}\right)$

$$
+.19(1-0.73)(.30)(\$ 21.95+\$ 23.62) \geq \$ 12.40
$$

After simplification, the condition becomes

(9) $6.35 t_{\mathrm{F}}+0.057 \rho_{\mathrm{F}}+.133 t_{\mathrm{F}} \rho_{\mathrm{F}} \geq \$ 10.44$

We have solved for the in-region footprint market share-content price pairs that would generate equal profits for AOL whether it engages in content discrimination or not (i.e., for which content discrimination generates zero incremental profit relative to no discrimination). Figure 3 plots those combinations (the zero-profit frontier), given AOL Time Warner's nationwide conduit footprint of 19 percent. Content discrimination will be profitable for all points above and to the right of this frontier. 
Figure 3: Necessary Conditions for AOL Time Warner to Engage in Content Discrimination

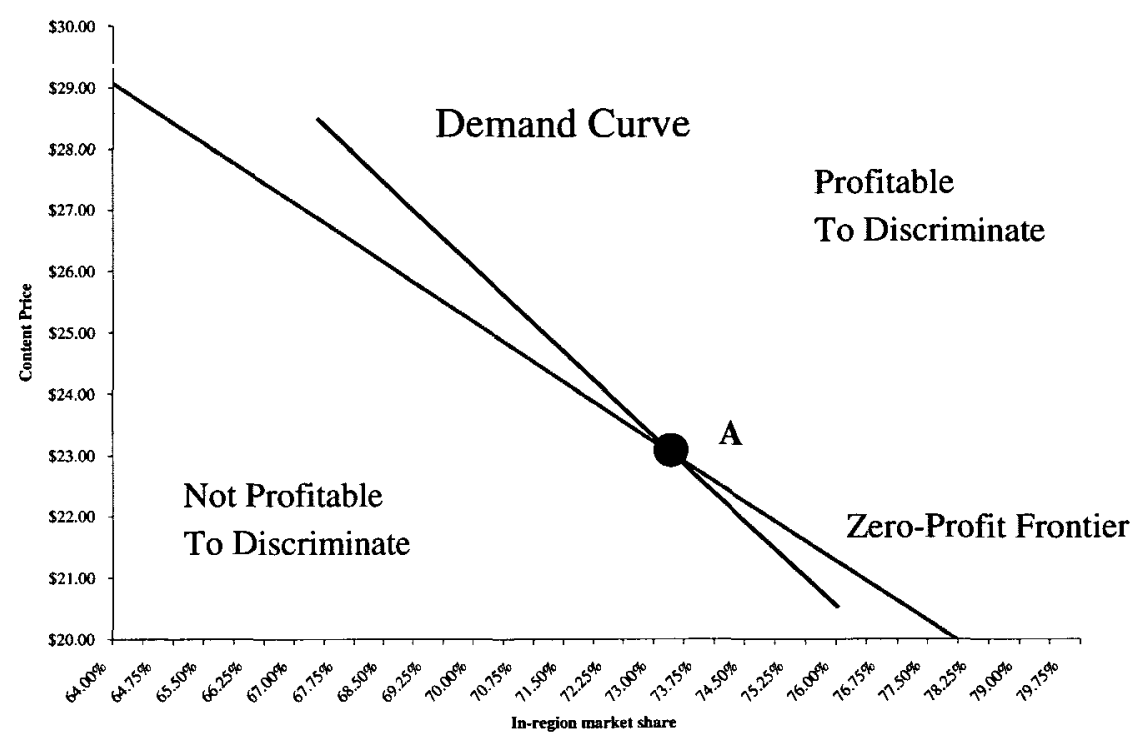

Currently, AOL's market share and content price put it at point A on the frontier. Discrimination will be profitable if the increased revenues from AOL Time Warner customers resulting from a higher content price will outweigh the lost revenues from customers who choose an alternative conduit. Suppose, for example, that AOL Time Warner pursued a discriminatory policy that allowed it to increase its monthly content price by $\$ 3$. Such discrimination would be profitable as long as AOL lost less than 5 percent of its in-region transport market share. Because this is such a small increase, we believe that AOL Time Warner's combined footprint is sufficiently large to encourage it to engage in content discrimination.

To develop this analysis further, we can ask more generally how much market share AOL Time Warner could lose as it increases the price of its content and advertising. This information is reflected in Figure 3 in the demand curve for broadband content conditional on AOL Time Warner engaging in content discrimination. As it is drawn, demand is sufficiently inelastic that the gains from greater in-region content revenues from inframarginal customers - customers who remain in spite of discriminationmore than compensate AOL Time Warner for the loss in revenues from 
marginal broadband customers. ${ }^{113}$ Stated differently, the demand curve lies above the zero profit frontier as content prices increase.

Similar to the analysis on conduit discrimination, we now examine the effect of an increase in the size of AOL Time Warner's cable distribution footprint on the profitability of engaging in content discrimination. Figure 4 demonstrates the results:

Figure 4: Effect of an Increase in the Size of the Conduit Footprint on the Profitability of Content Discrimination

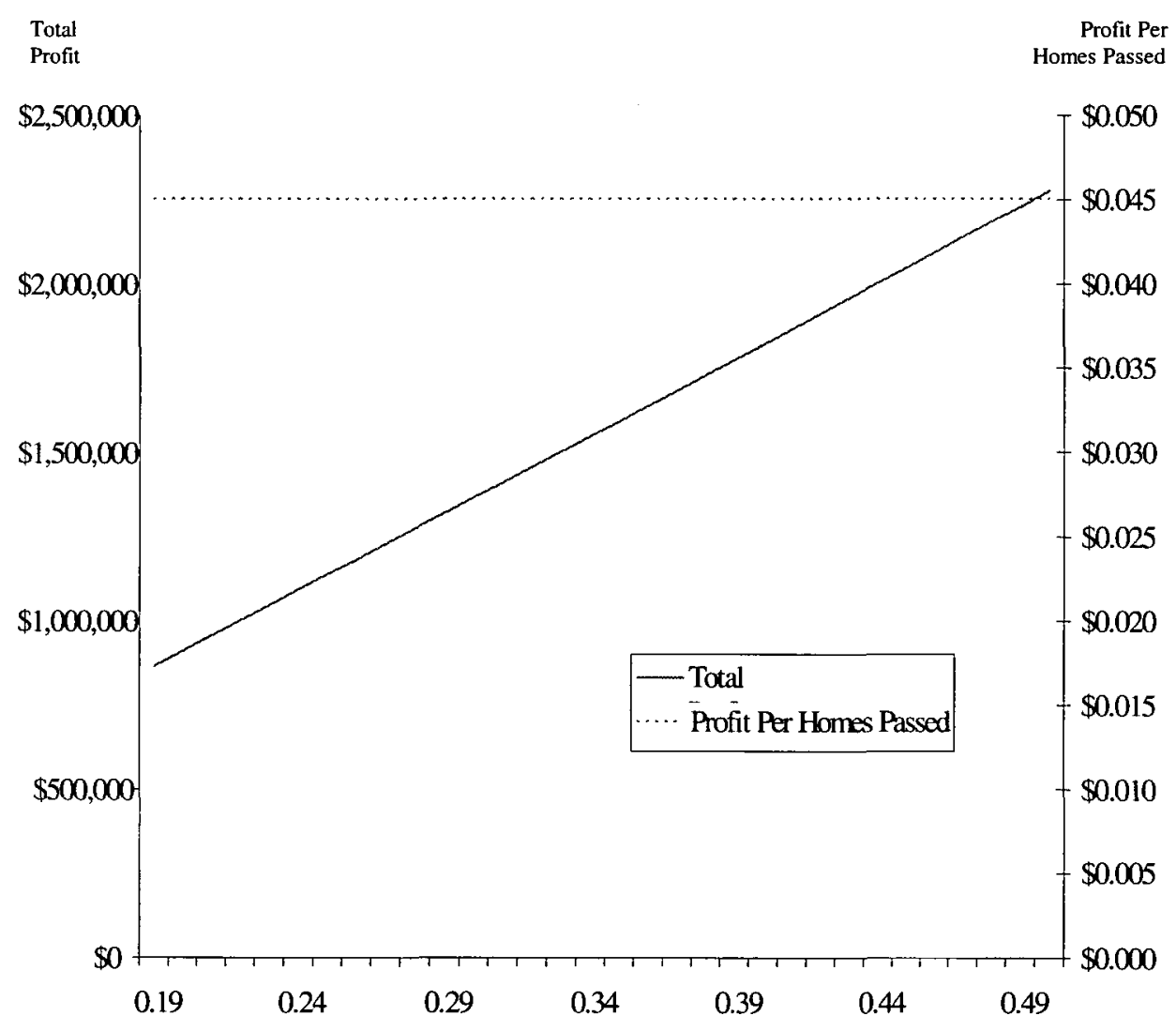

Cable Footprint

Note: Assumes in-region cable broadband market share of 70 percent and in-region content price of $\$ 28.00$.

The total profit line, which reflects the monthly increase in revenues across all AOL Time Warner broadband subscribers from engaging in

113. Of course, if the demand curve were flatter than the indifference frontier, AOL Time Warner would be worse off for engaging in content discrimination. 
content discrimination (the appropriate units of measurement are on the left-hand vertical axis), shows that AOL Time Warner would earn higher profits from content discrimination as the size of its distribution footprint increases. ${ }^{114}$ The total profit per homes passed curve, which is the total profit from discrimination divided by the number of homes passed by AOL Time Warner cable systems (the appropriate units of measurement are on the right-hand vertical axis), indicates that the monthly gains from discrimination on a per home basis remains constant as the size of the footprint increases. This leads us to Proposition 2.

Proposition 2: An increase in the size of a cable company's footprint will increase its incentive to engage in content discrimination so long as its in-region broadband access market share does not decrease significantly.

Proof: Define the critical market share, $t^{*}$, as $[t(p+\rho)+q(1-t)(o+\rho)$ $\left.-q\left(o+\rho_{\mathrm{F}}\right)\right] /\left[\left(p+\rho_{\mathrm{F}}\right)-q\left(o+\rho_{\mathrm{F}}\right)\right]$. The change in profit from engaging in content discrimination is

$$
\text { (10) } \begin{aligned}
\Delta \Pi=\Pi_{\mathrm{F}}-\Pi_{\mathrm{U}}= & k t_{\mathrm{F}}\left(p+\rho_{\mathrm{F}}\right)+k\left(1-\mathrm{t}_{\mathrm{F}}\right) q\left(o+\rho_{\mathrm{F}}\right)+(1-k)(1-\mathrm{t}) q(o+\rho) \\
& -k t(p+\rho)-\mathrm{k}(1-\mathrm{t}) q(o+\rho)-(1-k)(1-\mathrm{t}) q(o+\rho) \\
= & k\left[t_{\mathrm{F}}\left(p_{\mathrm{F}}+\rho\right)-t(p+\rho)\right]+k q\left[\left(1-\mathrm{t}_{\mathrm{F}}\right)\left(o+\rho_{\mathrm{F}}\right)\right. \\
& -(1-\mathrm{t})(o+\rho)]
\end{aligned}
$$

The derivative of the change in profit with respect to the size of the footprint is

(11) $\partial \Delta \Pi / \partial k=\left[t_{\mathrm{F}}\left(p+\rho_{\mathrm{F}}\right)-t(p+\rho)\right]+q\left[\left(1-\mathrm{t}_{\mathrm{F}}\right)\left(o+\rho_{\mathrm{F}}\right)-(1-\mathrm{t})(o+\rho)\right]$,

which is greater than zero whenever $t_{\mathrm{F}} \geq t^{*}$.

To evaluate the effects of footprint size on the profitability of content discrimination, note that because $t_{\mathrm{F}} \leq t$, the first term in square brackets in (11) is ambiguous. Because $\rho_{F} \geq \rho$, however, the second term in square brackets in (11) is unambiguously positive. Intuitively, because cable modems are the dominant broadband transport platform, a larger cable distribution footprint causes the vertically-integrated carrier to gain revenues from a larger number of customers. Whether the vertically-integrated provider enjoys gains or losses on in-region cable customers depends on the relative size of the infra-marginal and marginal revenues. We believe that content discrimination is likely to be profitable within the AOL Time

114. Total profit is defined as the product of the differential profit per broadband subscriber and the current number of nationwide broadband subscribers $(=1,980,000)$. 
Warner footprint (i.e., the derivative is positive). Therefore, a larger footprint would allow the combined company to capture even larger revenues through content discrimination by expanding its cable distribution footprint.

The analysis presented to this point has been conservative. In simplifying the analytics we omitted several important considerations that would likely increase the profitability of content discrimination. First, we have not taken into account the network effects that are likely to be associated with content provision. Due to network effects, the larger AOL Time Warner's customer base, the more likely that content discrimination will cause foreclosed content providers to either exit the market, or negotiate a deal with AOL Time Warner that gives them carriage in return for a substantial payment. To the extent that foreclosed competitors exit the market, AOL Time Warner is less likely to lose customers to a competing conduit because switching conduits will no longer afford customers access to foreclosed content.

The influence of network effects on the decision to discriminate can be portrayed in the context of Figure 3. We note that broadband sites are financed largely (for Yahoo!, entirely) by advertising revenue. The demand for advertisements to be placed on broadband sites is derived from the demand of broadband users who wish to access information on that site. By instilling loyalty and raising switching costs, the associated network effects tend to make customer demand for broadband content less price sensitive. Since the derived demand for advertising is positively related to the elasticity of demand for the underlying product, ${ }^{115}$ network effects make the demand for advertising itself less price sensitive. Hence, we expect the presence of network effects to shift the demand curve in Figure 3 upward, making content discrimination even more profitable.

Second, our analysis has focused on the most extreme form of content discrimination - the complete foreclosure of rival content to AOL Time Warner cable customers. A strategy of partial foreclosure, one that increases the cost of accessing rival content on its cable systems, also has the potential to be substantially profitable. Indeed, such a strategy, if successful, would have the potential to choke off the supply of rival content generally, and cause customers to shifts towards, rather than away from, cable transport as their preferred platform.

115. This is an application of Marshall's first rule of derived demand. See, e.g., P.R.G. LAYARD \& A.A. WALTERS, MICROECONOMIC THEORY 260 (1978). 


\section{Example of Content Discrimination in the Cable Television Industry}

As with conduit discrimination, cable providers have a history of engaging in content discrimination. Content discrimination in the cable television industry has historically taken the form of refusing to allow unaffiliated program providers to reach captive cable customers. The FCC, at the behest of Congress, took at least two steps to curb this type of discrimination. First, the FCC established a 30 percent limit on the number of homes passed that any single cable operator could reach. ${ }^{116}$ The motivation for this limit was that, even if 30 percent of the downstream market had been foreclosed due to discriminatory treatment by a cable operator, unaffiliated programmers would be able to reach enough consumers to achieve minimum viable scale. ${ }^{117}$ Second, the FCC imposed channel occupancy limits that precluded cable operators from filling more than 40 percent of their capacity with affiliated programming. ${ }^{118}$

Professors David Waterman and Andrew Weiss have reviewed the theory of vertical integration in the cable industry and documented the vertical relationships between cable program suppliers and cable operators. ${ }^{119}$ They also performed an econometric analysis of the effects of vertical integration on the carriage, pricing, and promotion of cable networks. ${ }^{120}$ Their study demonstrates that integrated cable systems tend to favor their affiliated programming, either by carrying those networks more frequently, by pricing them lower, or by marketing them more vigorously. ${ }^{121}$ For example, they found that ATC (then a subsidiary of Time Inc.) carried Showtime and The Movie Channel (two unaffiliated premium networks) nearly 40 percent less than the percentage rate predicted if the multiple cable system operator did not own its own competing affiliated channels. ${ }^{122}$ Because the discriminatory treatment seems to lessen when one controls for channel capacity, however, they believe that

116. 47 C.F.R. $\$ 76.503$ (2000); 47 U.S.C. $\$ 533(f)(1)(A)$ (Supp. 2000). The U.S. Court of Appeals for the District of Columbia has since struck down this regulation as arbitrary. See Time Warner Entm't v. FCC, 240 F.3d 1126 (D.C. Cir. 2001).

117. LELAND L. JOHNSON, TOWARD COMPETITION IN CABLE TELEVISION 98 (1994).

118. 47 C.F.R. $§ 76.504$ (2000); 47 U.S.C. $\$ 533(f)(1)(A)$ (Supp. 2000). See supra text accompanying note 116 .

119. DAVID WATERMAN \& ANDREW A. Weiss, Vertical INTEGRATION IN CABLE TELEVISION 35-37 (1997).

120. Id. at 87-98.

121. See id. at 101.

122. Id. at 91 . 
the results could be consistent either with the realization of transactions efficiencies or vertical foreclosure models. ${ }^{123}$

Waterman and Weiss conclude that conduct-type remedies aimed at limiting discriminatory behavior by vertically integrated cable systems against unaffiliated program suppliers are "impractical or counterproductive and should be abandoned." 124 They argue further that channeloccupancy limits do little to deter discrimination, "except to the extent that they induce vertical divestiture." the horizontal ownership restrictions from the current 30 percent limit to 20 percent, to reduce any one cable operator's monopsony power over programming. ${ }^{126}$ This conclusion fully supports our finding that increasing the size of AOL Time Warner's cable distribution footprint (through an access deal with AT\&T, for example) increases the likelihood of content discrimination.

\section{IMPLICATIONS FOR CONDITIONS ON THE MERGER OF AOL AND TIME WARNER}

In this Article we have not attempted to evaluate fully all of the likely benefits and costs of the AOL and Time Warner merger. Our analysis has shown that a policy of partial or complete conduit discrimination may be profitable post acquisition and that an agreement with AT\&T will substantially increase the risk of conduit discrimination. Further, we have shown that content discrimination is likely to be profitable post-acquisition, and that a deal between AOL Time Warner and AT\&T will increase the risk of such discrimination.

We have couched our analysis in terms of the profitability of conduit and content discrimination. In doing so, we have left implicit the injury such discrimination will impose on consumers. We believe that the potential harms can be significant for several reasons. Conduit discrimination will, if successful, lead to higher cable transport prices for AOL Time Warner customers. Further, customers out-of-region will also be worse off because they will face a diminished opportunity to purchase AOL Time Warner's content. Content discrimination will force consumers to pay more for broadband content (for example, through higher prices for goods sold in ways that rely on broadband advertising), and will force advertisers to pay more to reach AOL Time Warner's captive customer base. More-

123. Id. at 93 .

124. Id. at 7 .

125. Id.

126. Id. at 8 . 
over, those AOL Time Warner cable customers who switch to an alternative conduit will be worse off because they are forced to choose their second-best rather than their first-best broadband alternative.

To remedy the risks of conduit and content discrimination, an open access condition seems particularly worthy. It is reasonable to require that AOL Time Warner afford unaffiliated ISPs equal and nondiscriminatory access to the combined company's cable modem platform. AOL Time Warner signaled its willingness to open its network to competing ISPs in its Memorandum of Understanding, ${ }^{127}$ and to ensure that the combined company actually follows through on its promise, an open access provision is appropriate. Doing so ensures that AOL Time Warner does not evade or delay the advent of open access, promotes investment in the broadband portal market by giving new entrants certain access to the merged company's cable customers, and limits AOL Time Warner's ability to engage in both conduit and content discrimination.

We therefore believe that the open access provisions that were included in the recent FTC consent decree are appropriate. The consent decree deals with our content discrimination concerns by requiring that AOL Time Warner make EarthLink-and its associated content-available to Time Warner customers before AOL itself can begin offering its service in major markets. ${ }^{128}$ The companies also must strike deals with two other competing Internet providers within ninety days of making AOL available to Time Warner subscribers in major markets. ${ }^{129}$ The decree also requires that Time Warner open its cable lines in its smaller markets to three nonaffiliated Internet providers within ninety days of making AOL's cable service available. ${ }^{130}$ Under a "most favored nation" clause, Time Warner cannot strike a deal with another Internet provider that is any worse than the EarthLink agreement, or any other accord that AOL negotiates to carry its content on other cable systems. ${ }^{131}$ Moreover, the agreement puts in place measures to ensure that the company does not favor its cable Internet

127. Memorandum of Understanding Between Time Warner Inc. and Am. Online, Inc. Regarding Open Access Business Practices, II 1, In re Applications for Consent to the Transfer of Control of Licenses and Section 214 Authorizations by Time Warner Inc. and Am. Online, Inc., Transferors, to AOL Time Warner, Inc., Transferee, 2001 F.C.C. LEXIS 432 (Jan. 22, 2001) (No. 00-30), http://www.fcc.gov/csb/aoltw/mou.txt.

128. Alec Klein, AOL Merger Clears Last Big Hurdle; FTC Mandates Open Access To Time Warner's Cable, WASH. POST, Dec. 15, 2000, at A1; In re Am. Online, Inc. and Time Warner Inc., No. C-3989, 2000 F.T.C. LEXIS 170 (Dec. 14, 2000).

129. In re Am. Online, 2000 F.T.C. LEXIS 170, § II.A.2.

130. Id. § II.B.1.

131. See id. § II.C.1. 
access service over competing high-speed service utilizing DSL. This responds directly to our concern about conduit discrimination. ${ }^{132}$

The possibility of content discrimination with respect to instant messaging services was separately addressed in the consent decree reached with the Federal Communications Commission. ${ }^{133}$ AOL Time Warner must allow at least one instant-messaging rival to connect to its system before it offers advanced instant-messaging services (such as video conferencing) over its cable network. Subsequently, within 180 days of executing its first contract, it must sign up two additional significant and unaffiliated instant-messaging firms. When one considers AOL's instantmessaging customers as the "content" themselves, AOL's refusal to allow instant-messaging customers from other vendors (such as MSN Messenger Service) to communicate with AOL's instant-messaging customers is a form of content discrimination - that is, a customer can only view AOL's instant-messaging customers when using AOL instant-messaging software. Hence, the FCC's condition to allow at least one instant-messaging rival to connect to its system should undermine such discrimination.

To sum up, we are confident that the open access condition will undermine AOL Time Warner's ability to engage in conduit discrimination by ensuring the preservation of a robust broadband portal marketplace. Thus, even if the combined company elects to distribute its service only through cable modems, competing unintegrated portals can still take advantage of cable's dominant position in the broadband transport market, leaving competing conduit providers with enough content to justify continued investment. Likewise, the open access condition should undermine AOL Time Warner's ability to engage in content discrimination. Even if the merged company elects to block all outside content, unaffiliated portals and content providers can still reach cable customers through a com-

132. See id. § IV.A.

133. The FCC decision allows AOL Time Warner to seek a waiver from the instant-messaging condition if changes in the marketplace occur, or if it can demonstrate that an industry-wide standard of interoperability has been adopted. . . . In addition to the conditions governing instant messaging, the FCC also included some language to protect small and regional Internet providers that want to provide high-speed service over AOL Time Warner's cable network.

Alec Klein, FCC Clears Way for AOL Time Warner Inc; Vote is 5-0, but Conditions on Messaging Draw Dissents, WASH. POST, Jan. 12, 2001, at Al. The order also stipulates that "the company cannot discriminate against nonaffiliated Internet providers in the technical quality of service. The FCC requires that AOL bargain in 'good faith' with these Internet providers." Id. 
peting ISP. Thus, customers seeking access to foreclosed content will not have to switch to another transport conduit that suffers from a lower rate of market penetration.

We note in conclusion that the AOL Time Warner merger raises special issues with respect to vertical integration and vertical discrimination. An abstract cable company with no market power in broadband content would not have the same incentive as would AOL Time Warner. Stated differently, it is possible that the open access regime imposed in this context would not be appropriate in other contexts. With the continuing growth of the high technology sector, it is likely that we will see an increasing number of vertical mergers over the next decade. From a policy perspective, we believe that each prospective merger should be considered on a case-by-case basis as we have done herein. 
BERKELEY TECHNOLOGY LAW JOURNAL 